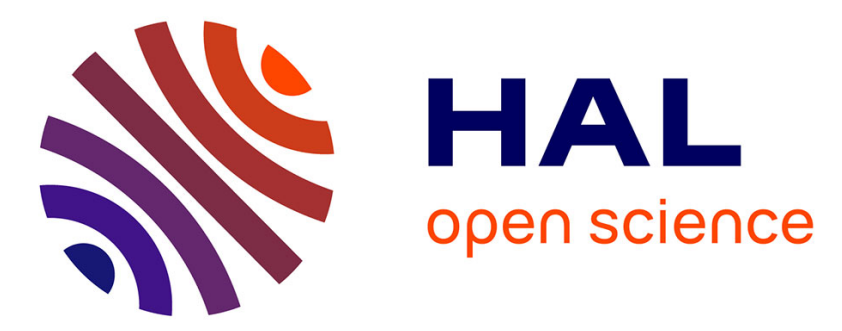

\title{
New tectono-sedimentary evidences for Aptian to Santonian extension of the Cretaceous rifting in the Northern Chotts range (Southern Tunisia)
}

Mohamed Gharbi, Amara Masrouhi, Nicolas Espurt, Olivier Bellier, El Amjed Amari, Mohamed Ben Youssef, Mohamed Ghanmi

\section{To cite this version:}

Mohamed Gharbi, Amara Masrouhi, Nicolas Espurt, Olivier Bellier, El Amjed Amari, et al.. New tectono-sedimentary evidences for Aptian to Santonian extension of the Cretaceous rifting in the Northern Chotts range (Southern Tunisia). Journal of African Earth Sciences, 2013, 79, pp.58-73. hal-01837215

\section{HAL Id: hal-01837215 https://hal-amu.archives-ouvertes.fr/hal-01837215}

Submitted on 27 Aug 2018

HAL is a multi-disciplinary open access archive for the deposit and dissemination of scientific research documents, whether they are published or not. The documents may come from teaching and research institutions in France or abroad, or from public or private research centers.
L'archive ouverte pluridisciplinaire HAL, est destinée au dépôt et à la diffusion de documents scientifiques de niveau recherche, publiés ou non, émanant des établissements d'enseignement et de recherche français ou étrangers, des laboratoires publics ou privés. 


\section{Accepted Manuscript}

New tectono-sedimentary evidences for Aptian to Santonian extension of the

Cretaceous rifting in the Northern Chotts range (Southern Tunisia)

Mohamed Gharbi, Amara Masrouhi, Nicolas Espurt, Olivier Bellier, El Amjed

Amari, Mohamed Ben Youssef, Mohamed Ghanmi

PII:

S1464-343X(12)00202-6

DOI:

http://dx.doi.org/10.1016/j.jafrearsci.2012.09.017

Reference:

AES 1804

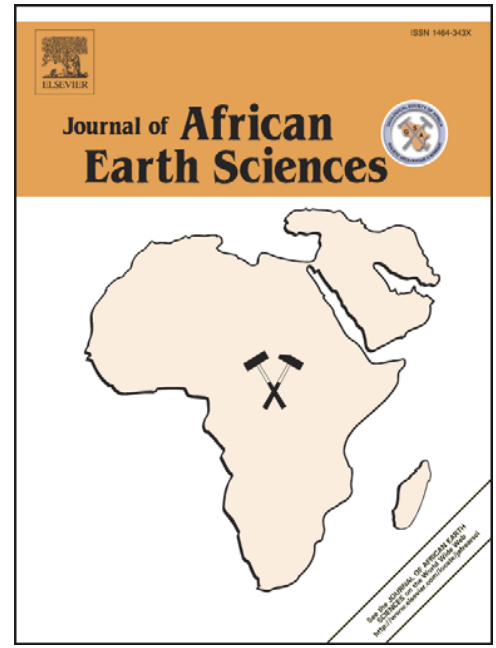

To appear in:

African Earth Sciences

Received Date:

18 April 2012

Revised Date:

21 September 2012

Accepted Date:

30 September 2012

Please cite this article as: Gharbi, M., Masrouhi, A., Espurt, N., Bellier, O., Amari, E.A., Youssef, M.B., Ghanmi, M., New tectono-sedimentary evidences for Aptian to Santonian extension of the Cretaceous rifting in the Northern Chotts range (Southern Tunisia), African Earth Sciences (2012), doi: http://dx.doi.org/10.1016/j.jafrearsci. 2012.09.017

This is a PDF file of an unedited manuscript that has been accepted for publication. As a service to our customers we are providing this early version of the manuscript. The manuscript will undergo copyediting, typesetting, and review of the resulting proof before it is published in its final form. Please note that during the production process errors may be discovered which could affect the content, and all legal disclaimers that apply to the journal pertain. 


\section{New tectono-sedimentary evidences for Aptian to Santonian extension of}

\section{2 the Cretaceous rifting in the Northern Chotts range (Southern Tunisia)}

3 Mohamed Gharbi $^{\mathrm{a}, \mathrm{b}^{*}}$, Amara Masrouhi ${ }^{\mathrm{a}, \mathrm{b}}$, Nicolas Espurt ${ }^{\mathrm{b}}$, Olivier Bellier ${ }^{\mathrm{b}}$, El Amjed Amari ${ }^{\mathrm{a}}$,

4 Mohamed Ben Youssef $^{\mathrm{c}}$ and Mohamed Ghanmi ${ }^{\mathrm{d}}$.

5 a Département des Sciences de la Terre, Faculté des Sciences de Gabès, Université de Gabès,

6 Cité Erriadh, 6072 Gabès, Tunisia

7 b Aix-Marseille Université, Institut Pytheas, CNRS, CEREGE UMR 7330, Aix-en-Provence,

8 France

9 c Centre de Recherches et Technologies des Eaux, BP 273, 8020 Soliman, Tunisia

10 d Département de Géologie, Faculté des Sciences de Tunis, 1060 Tunis, Tunisia

11 "corresponding author; gharbim.mohamed@gmail.com phone: +216 75 392600; fax: +216 75

$12 \quad 392421$

13 Abstract

14 Based on new structural, sedimentary, stratigraphic and seismic reflection data from

15 Cretaceous sequences of the Zemlet el Beidha anticline of the northern Chotts range (South

16 Tunisia), this study yields fresh insights into the geodynamic evolution of the South Tethyan

17 margin. The rifting of the margin started in the Triassic-Jurassic and continued during the

18 Aptian-Albian. In this last period N to NE trending extension was associated with WNW and

19 NW trending normal faults, bounding the developing horsts and grabens structures. This

tectonic framework is highlighted by strong thickness and facies changes in the Aptian-Albian

21 series associated with slumps and syntectonic conglomerates. During the Coniacian to

22 Santonian times, the study area was characterized by continued subsidence. Consequently, the

23 Coniacian-Santonian series are represented by sedimentary infilling consisting of post-rift

24 marl-rich sequences followed by limestone and marl sequences. 
Folds geometry and associated faults system and tectonics analysis, confirm the role of

the Aptian-Albian rifting inheritance faulting in the structuring and the development of the

folds and thrusts belts of the southern Tunisian Atlas during the Cenozoic inversion, in particular in the development of the ENE striking structures such as the Zemlet el Beidha anticline.

\section{Keywords:}

South Tethyan margin, Rifting, Aptian-Santonian, Southern Atlassic domain, Tunisia, Chotts range, Zemlet el Beidha anticline

\section{Introduction}

The geodynamic evolution of the northern margin of Africa has been studied by many authors (Dercourt et al., 1986; Philip et al., 1986; Dewey et al., 1986; Soyer and Tricart, 1987; Guiraud and Maurin, 1991; 1992; Martinez et al., 1991; Piqué et al., 2002; Bouaziz et al., 2002; Burnet and Cloetingh, 2003), observing, that this margin was characterized by (1) the extension, crustal stretching and thinning, as well as subsidence during the Mesozoic Tethyan rifting (Bouaziz et al., 2002; Piqué et al., 2002; Bumby and Guiraud, 2005), and (2) the occurrence of subsequent inversion during Late Cretaceous-Cenozoic subduction and collision (Guiraud et al., 1991; Guiraud and Bosworth, 1997; Guiraud, 1998; Laville et al., 2004; Abrajevitch et al., 2005; Bumby and Guiraud, 2005; Dhari and Boukadi, 2010). Along the northern margin of Africa, the rifting began during the Late PermianMiddle Triassic period (Raulin et al., 2011), and culminated at the transition between the Triassic and Jurassic. The Early Mesozoic transgressions are characterized by a heterogeneous sedimentary cover (Piqué et al., 2002; Courel et al., 2003; Guiraud et al., 2005). During this sedimentation cycle an extensional tectonic context predominated, as indicated by numerous synsedimentary normal faults systems. During the Jurassic time, a regional extensional tectonic regime produced the dislocation of the existing continental 
50 platform, which is related to the opening of the Central Atlantic and led to the development of

51 "en échelon” normal faults, tilted blocks and volcanic activity (Laridhi Ouazaa and Bédir,

52 2004). The distribution of the sedimentary facies has taken place along the WSW trending

53 Atlassic range from Morocco to northern Tunisia during the Late Liassic-Early Cretaceous

54 period (Piqué et al., 2002; Guiraud et al., 2005).

55 In southern Tunisia, the rifting has been associated with the development of WNW to

56 NW trending half grabens related to high rate subsidence, especially during Neocomian and

57 Barremian (Piqué et al., 1998; Bouaziz et al., 2002; Guiraud et al, 2005; Herkat et al., 2006).

58 The rifting led to presence of unconformities within many basins in the Early Aptian (Guiraud

59 and Maurin, 1991; 1992; Zouaghi et al., 2005b; Bodin et al., 2010) and continued during the

60 Aptian-Albian creating N to NE trending regional extension (Zghal et al., 1998; Rigane et al.,

61 2010). The Early Aptian unconformities mentioned above are associated with the lower

62 Cretaceous rifting stage. On the contrary, these later are related by some authors to the

63 compressional regime (Austrian Event; Ben Ayed, 1993; Bedir et al., 2001; Zouaghi, al.,

64 2005; Lazez et al., 2008) and/or halokinetic movements (Rigane et al., 2010; Zouaghi, al.,

65 2011).

66 Along the southern margin of Tunisia, the rifting has been associated with volcanism

67 in the Pelagian block (Fig. 1A; Ouazaa and Bédir, 2004). Extensional structures have been

68 recognized by surface and subsurface data in the Northern African margin (Piqué et al., 2002;

69 Bumby and Guiraud, 2005; Guiraud et al., 2005). The Cretaceous evolution of this margin

70 was associated with thickness and facies variations of the sedimentary sequences (Ben

71 Youssef et al., 1985; Ben Ferjani et al., 1990; Delteil et al., 1991; Abdallah et al., 1995;

72 Souquet et al., 1997; Bédir et al., 2001; Patriat et al., 2003; Zouaghi et al., 2005). This

73 tectonic regime involved the reactivation of pre-existing (Early Cretaceous) passive margin

74 structures, with a maximum extension occurring during Albian times. Early Cretaceous 
75

76

77

78

79

80

81

82

83

84

85

86

87

88

89

90

91

92

93

94 95 Abdeljaoued and Zargouni, 1981; Burollet, 1991; Bédir et al.; 2001, Hlaiem, 1999; Bouaziz et

extensional structures have been sealed by Senonian post-rift series with reefal buildings along uplifted ridges (Negra et al., 1995). Thereafter, during Late Cretaceous and Cenozoic times, tectonic inversion occurred as a result of convergence between Africa and Eurasian plate. The North African margin was characterized by the reactivation of pre-existing extensional faults systems which controlled fault-related folds (Zargouni, 1985; Ben Ayed, 1986; Catalano et al., 1996; Doglioni et al., 1999; Vergés and Sabat, 1999; Frizon de Lamotte et al., 2006; Masrouhi et al., 2007; Dhahri and Boukadi, 2010).

This study focuses on the structure of the Zemlet el Beidha anticline in the eastern part of the northern Chotts range, which belongs to the southern Atlassic front of Tunisia. In this area, the tectono-sedimentary framework displays evidence for the southernmost Cretaceous rifting. Our study provides new structural elements, new detailed geologic mapping, sedimentologic, palaeontologic and new interpretation of geophysical data to understand the Cretaceous passive margin evolution.

\section{Geological setting}

\subsection{Structural features of the study area}

The Atlas orogen forms a part of the present-day North African margin and is the result of the collision between the African and the European plates. The development of the southern Tunisian Atlas fold-and-thrust belt is related to this tectonic convergence occurred during Tertiary times. This domain is characterized by E-W to NE-SW and NW-SE anticlines separated by synclines filled with Neogene and Quaternary series (Fig. 1B; Zargouni, 1985; al, 2002).

The southern Tunisian Atlas fold-and-thrust belt is limited westward by major NW 98 al, 2002). trending strike-slip fault systems (Gafsa and Negrine-Tozeur fault systems; Fig. 1A, B). The 
1B, C). The Chott El-Fejej occupies the core of a mega-anticline called "Fejej dome" whose

112 southern limb corresponds to Jebel Tebaga and northern limb is formed by the northern 113 Chotts range (Fig. 1B, C). The eastern part of the northern Chotts range fold belt is affected by several faults 115 that's the most significant is the Bir Oum Ali and Fejej faults system (Fig. 1B). The northern 116 Chotts range (E-W trend) changes direction to a NE-SW in its eastern part that corresponds to 
117 the Zemlet el Beidha anticline. The Zemlet el Beidha anticline limits the Sidi Mansour basin

118 in the north and the Chotts Fejej basin in the south (Fig. 1C). The Zemlet el Beidha anticline

119 (Fig. 2) belongs to the southern Atlassic front of Tunisia in the eastern part of the northern

120 Chotts range (Fig. 1B). It is located between an intensely deformed domain, the southern

121 Atlassic fold-and-thrust belt, in the north, and a less deformed domain, the Saharan Platform,

122 in the south (Fig. 1A, B), (Zargouni, 1984; Ben Ferjani et al., 1990; Burollet, 1991; Haleim,

123 1999; Bouaziz et al., 2002).

\subsection{General stratigraphy}

125

126

127

128

129

130

131

132

133

134

135

136

137

138

139

140
The stratigraphy (Fig. 3) of the Zemlet el Beidha region is derived from

micropaleontology analysis (Table. 1) and from boreholes which were drilled close to the anticline (wells 1, 2, 3 and 4, Fig. 1 C). The sedimentary series outcropping in the study area are Cretaceous to Quaternary in age (Fig. 1C, 2 and 3). The core of the Zemlet el Beidha anticline (Fig. 2) is formed by Hauterivian-Barremian marls, alternating with anhydrites, limestones and claystones of the Bouhedma Formation (Abdejaouad and Zargouni, 1981; Lazez and Ben Youssef, 2008). The Bouhedma Formation is overlain by shale-rich sands and ferruginous sandstones of the Sidi Aïch Formation, for which a Barremian (pro parte) age is deduced from its stratigraphic position. The Sidi Aich Formation is overlain by the dolomitic bank of the Lower Aptian Orbata Formation (Ben Youssef and Peybernes, 1986; Chaabani and Razgallah, 2006), which is topped by a rich-Orbitolinidae hardground, showing some Ammonites (Gharbi, 2008). This massive dolomitic bank is a common feature all over the area and forms the flanks of folded structures. The Upper Albian deposits correspond to the lower member of the Zebbag Formation. This formation, which rarely outcrops in the study area, is dominated by dolomitic sandstones, marls, limestones and argillaceous limestones. The upper member of Zebbag Formation (Upper Cenomanian-Turonian) is characterized by 
141 the flint dolomitic bank of the Guettar member. This sequence is only deposited at Jebel

142 Jerouala (Fig. 2). The Coniacian-Santonian series of the Aleg Formation unconformably

143 overlie the previous series. They are defined by thick sequences of dolomitic sandstones at the

144 base and interbedded green marls and bioclastic limestones at the top. The fauna of this

145 formation is distinguished (Fig. 3 and Table. 1) by the ammonites in the Khanguet Aïcha

146 River, planktonic foraminiferas in the Gouada plain and the Rudistes in the Khanguet Telmem

147 (Abbès and Tlig, 1991; Louhaïchi and Tlig, 1993; Gharbi, 2008). The Abiod Formation

148 conformably overlies the Aleg Formation and consists of limestone banks with intercalations

149 of thin clay layers. These intercalations are enriched by phosphatic debris and glauconite

150 grains. The associated fauna suggests a deep marine environment, similar to the central and

151 northern Tunisian domain (Abdeljaouad and Zargouni, 1981). According to facies (Louhaïchi

152 and Tlig, 1993) and microfauna data (Gharbi, 2008), the Abiod Formation is Upper

153 Campanian to Maastrichtian in age (Fig. 3 and Table. 1).

154 The Cenozoic series of the study area are composed by thin Paleocene marine marls

155 covered by Paleogene and Neogene continental sediments. The Early Tertiary comprises

156 green clays of the El Haria Formation. The clays show a Maastrichtian to Paleocene marine

157 fauna (Gharbi, 2008). The Bouloufa Formation is dated to the Middle Eocene by Abdeljaouad

158 (1987) and overlies unconformably (U1) the clays of the El Haria Formation. It is formed by

159 red gypsum clay and encrusted limestone with Bulimes fauna. At the end of Eocene period,

160 south and central Tunisia emerged and compressional deformations took place (Masrouhi et

161 al., 2008; Frizon de Lamotte et al., 2009). As a result, intense erosion in the Atlassic fold-and-

162 thrust belt zone caused the deposition of thick syntectonic series of silt and molasse basins

163 during the Neogene and Quaternary. Miocene sands of the Beglia Formation unconformably

164 overlie (U2) the Bouloufa Formation. Finally, the Segui Formation, which crops out on the

165 southern flank of the Zemlet el Beidha anticline, consists of coarse alluvial conglomerate 
166

167

168

169

170

171

172

173

174

175

176

177

178

179

180

181

182

183

184

188

189

deposits. The Segui Formation unconformably overlies (U3) the Beglia Formation and record the growth of the Zemlet el Beidha anticline.

\section{Zemlet el Beidha Cretaceous structures}

\subsection{Structures}

The Zemlet el Beidha structure corresponds to a south-verging asymmetric thrustrelated anticline with a curved axis that changes from an E strike to NE strike from west to east (Fig. 2). The Zemlet el Beidha anticline has a single periclinal closure in the east. As shown in geologic map of Figure 2, the core of the Zemlet el Beidha consists of ConiacianSantonian outcrops in the Jebel Romana and Gouada plain (NE part of Zemlet el Beidha). Westward, the anticline of Jebel Haidoudi is occupied by the Coniacian-Santonian deposits. In the central part, the core of the anticline is formed by the Hauterivian-Barremian series. The geometry of the Zemlet el Beidha anticline is illustrated by the two cross sections of Figure 4. The section A-A' crosses the eastern part of the anticline (Fig. 2 and 4). In the Tebaga Fatnassa region, the fold corresponds to a gently deformed anticline of Cretaceous strata unconformably overlain by Late Miocene (U2) and Late Pliocene to Quaternary series (U3). The northern backlimb is formed by $\sim 10^{\circ} \mathrm{N}$-dipping thin layers of marls (Fig. 4A), alternating with anhydrites, limestones and claystones of the Bouhedma Formation. The series are also deformed by the N-dipping normal faults. The southern forelimb is formed by Coniacian-Santonian series of the Aleg Formation and dips $\sim 20^{\circ}$ southeastward. The central part, the Khanguet Aïcha and Khanguet Amor region, exposes a forelimb formed by almost $45^{\circ}$ S-dipping layer (Fig. 2 and 5). The southern flank of the Zemlet el Beidha anticline also shows subvertical faults, previously interpreted by several authors as strike-slip faults (Abdeljaouad and Zargouni, 1981; Zargouni et al., 1985; Abbès and Zargouni, 1986; Abbès et al., 1986). 
Along the cross section B-B' (Fig. 4), the northern limb of the anticline exhibits 5-10

191

192

193

194

195

196

197

198

199

200

201

202

203

204

205

206

207

208

209

210

211

212

213

N-dipping Hauterivian-Barremian series. The cross section B-B' shows a Cretaceous series

from the Hauterivian to Late Maastrichtian unconformably overlain by Middle Eocene, Late

Miocene and Late Pliocene to Quaternary $(\mathrm{U} 1,2,3)$ series on the Jebel Jerouala and Jebel

Haidoudi (Figs. 2 and 4).The western part of the Zemlet el Beidha anticline is characterized

by a $70^{\circ}-80^{\circ} \mathrm{S}$-dipping forelimb intensively deformed by the S-vergent faults acting now as right-lateral oblique-slip of the Fejej coridor (Fig. 2).

\subsection{Fault kinematics analysis}

The Zemlet el Beidha area has undergone a complex tectonic evolution related to its geometric position in relation to the whole northern Chotts range. To support our structural interpretation we measured and analyzed striated fault planes within Aptian-Albian series.

Such a fault kinematics analysis of mesoscale faults permits a quantitative reconstruction of paleostresses that can be related to the chronological sequence and orientations of larger-scale structures. These paleostresses thus provide useful information not only on the compressional, extensional or strike-slip origin of larger structures, but also on their kinematics and orientation relative to the stress field (oblique or normal).

The western part of the Zemlet El Beidha anticline (Jebel Haidoudi, Jebel Fejej and Jebel Jerouala) is characterized by a major NW to WNW-trending fault Fejej system (Abdeljaouad and Zargouni, 1981; Zargouni et al., 1985; Abbès and Tlig, 1991; Louhaïchi and Tlig, 1993). This fault system, acting now with a right-strike-slip component, may correspond to inherited Cretaceous normal faults (Gharbi, 2008). The detailed geologic mapping (1:25 000) of the Khanguet Aïcha area (central part of Zemlet el Beidha, Fig. 2) combined with the SPOT images (Fig. 5A, B) also show numerous N100-110 E apparent trending strike-slip faults. These faults are well expressed in the southern flank of the Zemlet 
214 el Beidha anticline. The Khanguet Aïcha and the Khanguet Amor faults appear on map as 215 strike-slip faults. They affect the Hauterivian to Albian series and are sealed by Coniacian216 Santonian deposits (Fig. 5B, C) with no evidence of recent displacement (Fig. 5 and 6). Fault

217 kinematics analysis performed along the Khanguet Aïcha and Khanguet Amor faults (Fig.

218 5D) shows oblique strike-slip faulting component. The normal faulting generates the 219 sedimentary reworking of the Aptian dolomitic bank in the Khanguet Aïcha and Khanguet

220 Amor. The syntectonic Aptian conglomerates (Fig. 7 A, B, C and D) observed in the 221 downdropping normal fault of Khanguet Aïcha and Khanguet Amor (Fig. 6) indicated tilted 222 block geometry. In addition, the eastern part of Tebaga Fatnassa (Fig. 2) exposes growth 223 strata in the hanging-wall of the ancient normal fault testifying the Albian extensional regime 224 (Fig. 8).

Using the fault diagram, we rotated the fault data to restore the bedding plane to its 226 horizontal orientation. The resulting back-tilted fault diagram shows that these faults were 227 normal faults before Cenozoic tilting (Fig. 5D). This pre-tilting normal faulting shows a $\sim$ NE trending extension (Fig. 5D). The reactivation of this normal fault is attested by reverse sense of movement (Fig. 8) and shows thrust reactivation and the shortcut geometry affecting the Bouhedma Formation in the core of the Zemlet el Beidha anticline (Fig. 9).

\subsection{Tectono-sedimentary data} allows us to characterize at least four periods of tectono-sedimentary evolution related to the

234 Cretaceous rifting (Fig. 10A) i.e. Neocomian, Aptian-Albian, Coniacian-Santonian and Campanian-Maastrichtian tectono-sedimentary sequences.

237 regression. The sequences correspond essentially to continental sediment including sands, 
238 clays, silts, lacustrine dolomites and gypsum deposits. The Early Albian tectonic extensional

239 episode is recorded by $\mathrm{N} 100-110^{\circ}$ E trending faults related to a regional $\mathrm{N}$ to $\mathrm{NE}$ trending

240 extension. This tectonic episode may be associated with the general uplift and erosion (ds1) of

241 the Zemlet el Beidha zone (Fig. 10A) and continued to Early Albian times. The subsidence in

242 the northern Chotts range area began during the Hauterivian-Barremian. Sedimentary features

243 such as small slumps (Fig. 11 A), turbidites, mudflows (Fig. 11 B), and several meter scale

244 olistoliths (included within the Barremian anhydrites, limestones and claystones) indicate

245 basin instabilities. The Early Aptian dolomitic series include rare orbitolines and ammonites

246 (Fig. 11 C; Abdeljaouad and Zargouni, 1981; Ben Youssef and Peybernès, 1986; Chaabani

247 and Razgallah, 2006; Lazez et al., 2008; Gharbi, 2008) give evidence for a hard ground

248 surface. In the Khanguet Aïcha, this dolomitic bank is also affected by the $\mathrm{N} 110^{\circ} \mathrm{E}$ trending

249 faults. This faulting is associated with thickness and facies variations of the Barremian series

250 (Fig. 5C) as well as the occurrence of Aptian conglomerates within the hanging-walls of the

251 Kanguet Aïcha and Kanguet Amor faults (Figs. 5 and 6). These conglomerates probably attest

252 to syntectonic sedimentation during normal faulting. Moreover, the stratigraphic correlation

253 of Fig. 10A shows usually lateral thickness changes from the Khanguet Amor $(\log 7)$ to the

254 Kanguet Aïcha $(\log 8)$ areas that appear to be correlated with the normal faults. The Early

255 Aptian tectonic extensional episode is well known in the northern Chotts range and south

256 Atlassic domain. It is characterized by a tilted block system associated with horsts and

257 grabens. In fact, this structural frame is responsible for the distribution of the Albian

258 sequences in the northern Chotts range and the regional unconformity deposits which are

259 defined by the absence of the deposits of Late Aptian and of the Early and Middle Albian age

260 (Abdeljaouad and Zargouni, 1981; Ben Youssef et al., 1984; Lazez et al., 2008).

261 In this area, the irregular distribution of these series is also expressed within deposits

262 around the uplifted zone of the present-day Zemlet el Beidha fold (Fig. 10B). In this region, 
263 the series distribution is related to a tilted bloc geometry, which has been dated to the

264 Neocomian-Early Albian. Faulting produced differential uplift and high subsidence rates in 265 the northeastern Chotts range (Fig. 10B).

The transgressive Cenomanian and Turonian period is well known across the northern

267 African plate. Despite this transgression (Guiraud et al., 2005), the tectonic activity induced

268 differential subsidence; the Zemlet el Beidha formed an uplift zone during this period of high

269 sea level. The Jebel Jerouala is the unique locality (log 3 in Fig. 10A) where Turonian

270 sediments were deposited. In this zone we note the presence of red flint dolomite limited by

271 the Fejej normal fault systems. The thickness variations and the main tectonic elements

272 suggest that the Turonian sedimentation was controlled by WNW to NW trending faults.

273 The Coniacian-Santonian sedimentation is characterized by a subtle onlap pattern and

274 facies changes. These sediments consist of marl-rich limestones and clays enriched by benthic

275 and pelagic foraminifera and ostrea, indicating a deepening basin. On the northern side and

276 southern flank of the Zemlet el Beidha anticline, the strong thickness of the Coniacian-

277 Santonian series is related to the reactivation of NW trending faults that delimited the Zemlet

278 el Beidha horst (Fig. 2 and 10A). Eastward, the region of Gouada plain (Fig. 2) is

279 characterized by pelagic facies (Fig. 10A) while westward, at Jebel Haidoudi, the deposits are

280 characterized by benthic facies. In the Khanguet Telmem (Fig. 2 and $\log 5$ and 6 in Fig. 10A),

281 a lens of reef-building rudist colonies (Fig. 11D) has been observed, which recorded and

282 developed due to the Zemlet el Beidha uplift. The rudist coral limestones preferentially

283 developed on the horst of Zemlet el Beidha. During the Coniacian-Santonian stage, the

284 paleostructure of the Zemlet el Beidha limits SW and NE marginal zones with basin

285 sedimentation. In particular, the eastern Tebaga Fatnassa-Gouada plain and the western Jebel

286 Fejej-Haidoudi area are characterized by strong subsidence during the Coniacian-Santonian 
287 288

289

290

291

292

293

294

295

296

297

298

299

300

301

302

303

304

305 306

( $\log 1$, 2, 9, 10 in Fig. 10A). This subsidence is consistent with the previous tectonic context described above.

During the Campanian, the western part of the Zemlet el Beidha domain is characterized by marine transgression, recorded by the occurrence of deepwater limestones and clays, and pelagic facies in the Late Campanian. West of the Zemlet el Beidha area, just at the south of Jebel Fejej (Fig. 2 and Fig. $10 \log$ 1, 2 and 3) and on the Jebel Haidoudi, these series are transgressive, and a significant increase in thickness subsidence rate is recorded by the Late Maastrichtian series. In the Fejej graben, the structural evolution during the Campanian and Late Maastrichtian led to a significant subsidence increase as a consequence of the transtensional (Guiraud et Bosworth, 1997; Zouari et al., 1999) displacement of the Fejej fault.

\section{Discussion: Geodynamic evolution of the southern Atlassic margin}

\section{1. Cretaceous rifting inheritances}

\subsubsection{Aptian-Albian syn-rift}

The northern Chotts range was dominated by regional normal faulting. The WNW and NW trending faults were mainly inherited from the Jurassic and reactivated during the Early Cretaceous-Albian times (Gharbi, 2008). Seismic reflection profiles of Figure 12 illustrate the structural architecture of the southern Tethyan margin in the northern Chotts range. Analysis of the seismic profiles EL05 and EL07 crossing the Sidi Mansour Basin (Fig. 1C) permits to identify faults with normal components bounding the subsiding domains (Fig. 12). These faults are associated with other synthetic faults that have contributed to the formation of a major graben systems. The study area is marked by thick Hauterivian-Barremian and Albian deposits, which are progressively thickening, associated with listric faults (Fig. 12). The 
geometry and the thickness variations are interpreted to be related to the regional extensional

311 strain during the Aptian-Albian. The evolution proposed in Fig.13 shows a possible tectonic

312 scenario for the Zemlet el Beidha zone during Aptian-Albian faulting. The reactivation of the

313 Khanguet Aïcha fault is associated with syntectonic conglomerates and leads to produce an

314 unconformity at the base of the Upper Aptian series (Fig. 3, $\log$ 5, 8 in Fig. 10A and B, Fig.

315 13). Our observations suggest that this unconformity is associated with normal faults and an

316 extensional tectonic regime. Such as the Jebel Chemsi, Jebel Bir Oum Ali at west of Zemlet el

317 Beidha, Jebel Tebaga of Kebili (Fig. 14 a, b and c), the fault kinematics deduced from the

318 study of striated fault planes display evidence for the tectonic regime which is extensional

319 during the Aptian-Albian period. Geologic and geophysic data were integrated to confirm that

320 the syn-rift tectonic in the northern Chotts range is still related to the Early Albian. This

321 rifting has been accompanied by an episode of volcanism which is testified by basalt flows

322 observed in the pelagian blocks of eastern Tunisia (Fig. 1B; Ellouz et al., 2003; Ouazaa and

323 Bédir, 2004).

324 Many interpretations have been proposed to explain the Upper Aptian-Lower Albian

325

326

327

328 regional unconformity. Several authors interpret this unconformity as the result of a major compressional event during the Aptian-Albian time (the Austrian Phase, Ben Ayed, 1993;

Bédir et al., 2000; Bouaziz et al., 2002; Zouaghi et al., 2005). Other authors plead for an extensional event (normal faulting regime) (Martinez et al., 1991; Guiraud, 1998; Zghal et al., 1998; Zouari et al., 1999; Guiraud et al., 2005; Bodin et al., 2010; Rigane et al., 2010). Our observations yield fresh data to support an Aptian-Albian extensional deformation of the south Tethyan margin. This rifting episode ended with a regional unconformity identified by a hard ground surface, and halokinetic movements (Bédir et al., 2001; Rigane et al., 2010; Zouaghi et al., 2011). Thus, the Upper Aptian-Lower Albian unconformity can be related to intraplate extensional deformation linked to the opening of the central segment of the South 
335 Atlantic while the northward movement of part of the African Plate was accompanied by N

336 trending extension registered in the central African basins (Martinez et al., 1991; Guiraud and

337 Maurin, 1991; Guiraud et al., 2005) and northeastward movement of the Arabian-Nubian

338 block during the Aptian-Albian transition (Bodin et al., 2010).

\subsubsection{Coniacian-Santonian post-rift}

The Coniacian-Santonian stage is attested by thick deposits of pelagic and benthic

343 Santonian sequence observed in seismic profile (EL-05, Fig. 12) shows along-strike changed

344 in term of thickness which does not follow the usual hierarchies of the Early Cretaceous

345 sequences. The ancient normal fault systems controlled the distribution of the Coniacian-

346 Santonian deposits that are marked by a significant thickness and facies variations from

347 northwest to southeast (Fig. 12). The Coniacian-Santonian distribution of the sedimentary

348 deposits testifies for a post rift stage with major transgression (Abdallah and Rat, 1987;

349 Herkat and Guiraud, 2006).

350 During the Coniacian-Santonian, the Maghreb area was covered by an important

351 transgression leading to a very extensive marine incursion covering the northern platforms of

352 the Sahara domain corresponding to shallow sea characterized by the deposition of a

353 homogeneous carbonate platform (Zouaghi et al., 2005; Herkat and Guiraud, 2006; Frizon de

354 Lamotte et al., 2009). A subsiding deep-marine basin has been developed in the Aurès

355 (Herkat and Guiraud, 2006) that allows the deposition of black deep-marine shales in the

356 Tunisian Atlas, which is one of the most important hydrocarbon-source rocks of the Atlas

357 system (Bédir et al., 2001; Zouaghi el al., 2005; Frizon de Lamotte et al., 2009). 


\subsubsection{Campanian-Maastrichian tectonic reactivation}

Several authors have suggested tectonic inversion in the Tunisia Atlas since the

360 Campanian (Guiraud and Bosworth, 1997; Guiraud et al., 2005; Herkat and Guiraud, 2006;

361 Masrouhi et al., 2008; Frizon de Lamote et al., 2009; Masrouhi and Koyi, 2012). Zouari et al.

362 (1999) defined that the inversion occurred between middle Turonian and the Late

363

Maastrichtian. In our study area, Late Campanian to Paleocene series are absent in the eastern

364 Zemlet el Beidha region. However, these series develops westward in the Fejej corridor (Fig.

3652 and Fig. 10A). We propose that fault reactivation occurred during Late Campanian to

366 Paleocene, producing the westward migration of the subsidence from the Gouada plain to the

367 Fejej corridor (Fig. 10A). This tectonic event may be related to $\mathrm{N}$ trending compression which

368 reactivated the major inherited fault. This stage corresponds to southwestward migration of

369 the subsidence in the southern Atlasic domain, especially in the Gafsa Basin (Zouari et al., 370 1999).

\subsection{Implications for Cenozoic tectonic evolution}

372 In this study, field data show evidences for unconformities and syntectonic deposits

373 recording several periods of shortening during the Cenozoic. We present here the sedimentary

374 signatures of the different pulses of shortening associated with the development of the Zemlet 375 el Beidha fold.

376 According to the cross section A-A' (Fig. 4), the unconformity angle between the 377 Coniacian-Santonian and the erosional Late Miocene surface is $10^{\circ}$ while between Coniacian378 Santonian and Late Pliocene-Quaternary is about $20^{\circ}$. Locally south of the Jebel Jerouala, we 379 observed that the Late Middle Eocene unconformably overlie the Late Maastrichtian380 Palaeocene series (cross section B-B', Fig. 4). This unconformity confirms that the Zemlet el 381 Beidha Cretaceous basin was inverted during the Cenozoic. During the compressional 
382

383

384

385

386

387

388

389

390

391

deformations, some extensional structures were not reactivated (Fig. 2 and Fig 4) while others were reactivated and evolved to strike-slip faults, such as the apparent Khanguet Aïcha and Khanguet Amor strike-slip faults (Fig. 5 and Fig. 6) and reverse faults (Fig. 8).

In addition, some Atlassic folds are related to the early halokinesis during Jurassic and Early Cretaceous associated with the synsedimentary activity of some normal faults (Rigane et al., 2010). The seismic lines interpreted by several authors (e.g., Hlaiem, 1999; Frizon de Lamotte et al., 2000; 2009) show that the fold structures are associated with reverse deepseated faults rooting at depth within the Triassic levels. The position and orientation of preexisting structures would be related to the position of ancient normal faults which may be

probably linked to structural inheritance due to the Triassic-Jurassic to Aptian-Albian rift

392 (Guiraud, 1998; Guiraud et al., 2005). In our study area, the Upper Aptian-Albian normal 393 faulting also played a major role during Cenozoic compressions in controlling the structural 394 architecture of the Zemlet el Beidha anticline and probably, of others structures of the Chott 395 range.

\section{5. Conclusion}

397 The structural and tectono-sedimentary study of Jebel Zemlet el Beidha underlines the 398 predominant role of inherited structures acquired during the evolution of the southern Tethyan 399 margin, and their influence of the present-day geometry of the Atlassic fold belt. The geodynamic history of the Tethyan margin during the Cretaceous in the northern Chotts range

401 can be divided into three different tectonic events. The first syn-rift Aptian-Albian period 402 shows a general episode of variable depositional thickness and facies variations. It is 
403 dominated by an extensional stress regime. The onset of the tilted blocks along the N100-

$404110^{\circ} \mathrm{E}$ trending normal fault was associated with Upper Aptian syn-depositional

405 conglomerates. This extensional tectonics was also accompanied, in several regions of the 406 Atlas, by volcanic activity and halokinetic movement. The second Coniacian-Santonian

407 period corresponds to a post-rift stage with major marine transgression. The Coniacian-

408 Santonian extensional faulting is recognized in the southern Tunisian Atlassic domain. In

409 contrats, in Algeria and Morocco, the Coniacian-Santonian is characterized by the first period

410 of inversion tectonics (Herkat and Guiraud, 2006; Frizon de Lamotte et al., 2009). In our

411 study area, we propose that fault reactivation occurred during Late Campanian to Paleocene,

412 producing the westward migration of the subsidence. This tectonic event can be correlated

413 with the onset of the Africa-Eurasia convergence (Guiraud and Bosworth, 1997; Zouaghi et

414 al. 2005; Frizon de Lamotte et al., 2009). Major structural inversion of the Upper Aptian-

415 Albian normal faults occurred during successive Cenozoic compressions. This Cretaceous

416 inheritance controlled the structural architecture of the Zemlet el Beidha anticline and

417 probably of others structures of the Chott range.

418 Acknowledgments

419 This work is based on M. Gharbi’s Masters at "Faculté des Sciences de Tunis"

420 (Tunisia) and PhD research at "University of Sfax", "Unité de Recherche Hydrosciences

421 Appliquées à Gabés (06/UR/10-03)" (Tunisia) and at CEREGE (Université Paul Cézanne

422 Aix-Marseille (UPCAM), France). M. Gharbi benefits of a Foreign Affair Ministry (Ministère

423 des Affaires Etrangères) grant through French Embassy in Tunisia and a complement support

424 through the "Cotutelle de thèse" program (F2IR program - UPCAM ). Field has benefited

425 from financial support under UPCAM RFQ's International Relations. SPOT images were

426 provided thanks to the ISIS program (CCNES, distribution SPOT images S.A.). The Tunisian

427 Enterprise for Petroleum Activities (ETAP) and particularly A. Amri and Y. Bouazizi are 
428 429 430 431 432 433

434 435 436 437 438 439 440

thanked for providing access to the seismic lines. We are indebted to Nick Marriner and Rita

Katharina Kraus for comments and English language corrections. We are grateful to Dr. W. Bosworth and the anonymous reviewer for providing constructive reviews that significantly improved this article.

\section{References}

Abbès, A. et Tlig, S., 1991. Tectonique précoce et sédimentation de la série Crétacée dans le bassin des Chotts (Tunisie du sud) Géologie Méditerranéenne. Tome XVIII, n 3. pp, 149161.

Abbès, C et Zargouni, F., 1986. Anatomie d'un couloir de décrochements: le couloir de Hadifa (Chaîne Nord des Chotts-Tunisie). Rev. Sc. de la Terre, Vol. 4, Tunisie.

Abbès, C., Abdeljaouad, S. et Ben Ouezdou, H. 1986. Carte Geologique d'El Hamma au 1/100.000, feuille $n^{\circ} 74$. Institut National de recherche Scientifique de Tunisie et Service Geologique Nationale d’Office Nationale de Mines, Tunisie.

Abdallah, H. et Rat, P., 1987. Le rôle de la faille de Gafsa dans le jeu transgressif et régressif au Crétacé supérieur de la chaîne nord des Chotts (Tunisie). In Colloque: Transgressions et régressions au Crétacé (France et régions voisines), Dijon, 1985 (ed. Saloman, J.), Mémoires Géologiques de l’Université de Dijon 11. pp, 232-242

Abdallah, H., Memmi L., Damotte, R., Rat, P. and Magniez, Jannin F., 1995. Le Crétacé supérieur de la chaîne Nord des Chotts (Tunisie du centre-sud): Biostratigraphie et comparaison avec les régions voisines. Cretacrous Research, 16. P,487-538.

Abdeljaouad, S et Zargouni, F., 1981. Mise en évidence d’une tectonique intracrétacé dans le secteur de J. Zemlet El Beïda (chaîne des Chotts). Acte de 1er Congr. Nat. Sc. Terre, Tunis, t. I, p, 285. 
451 Abdeljaouad, S., 1987. Sur l’âge Paléocène supérieur-Miocène des dépôts continentaux à

452 calcrètes ou dolocrètes de la Formation Bouloufa en Tunisie méridionale. Conséquences

453 paléogéographiques. Bull. Soc. Géol. Fr, (8), t, III, n4. pp, 777-781.

454 Abrajevitch, A.V., Jason, R.A., Aitchison, J.C., Badengzhu, Davis, A.M., Jianbing Liu, J., and

455 Ziabrev, S.V., 2005. Neotethys and the India-Asia collision: insights from a palaeomagnetic

456 study of the Dazhuqu ophiolite, southern Tibet. Earth and Planetary Science Letters 233. pp,

$457 \quad 87-102$.

458 Aris, Y., Coiffait, P.E., Guiraud, M., 1998. Characterization of Mesozoic-Cenozoic

459 deformations and paleostress fields in the Central Constantinois, northeast Algeria.

460 Tectonophysics. 290. pp, 59-85.

461 Bédir, M., Boukadi, N., Tlig, S., Ben Timzal, F., Zitouni, L., Alouani, R. Slimane, F., Bobier,

462 C., and Zargouni, F., 2001. Subsurface Mesozoic basins in the central Atlas of Tunisia,

463 tectonics, sequence deposit distribution and hydrocarbon potential, AAPG Bull. 85, 5. pp,

$464 \quad 885-907$.

465 Ben Ayed, N., 1986. Evolution tectonique de l'avant-pays de la chaîne alpine de la Tunisie du

466 début du Mésozo à l’Actuel. Thesis es-sciences, Univ. Paris Sud, Orsay, 347 p.

467 Ben Ferjani, A., Burollet, P., F. and Mejri, F. 1990. Petroleum geology of Tunisia. Entreprise

468 Tunisienne d'activités pétrolières, 194p.

469 Ben Youssef, M., Biely, A., et Memmi, L., 1985. La Formation Orbata (Aptien) en Tunisie

470 méridionale précisions biostratigraphiques nouvelles. Notes service géologique de Tunisie, 471 n51. pp, 105-120.

472 Ben Youssef. M et Peybernes. B., 1986. Données micropaléontologiques et

473 biostratigraphiques nouvelles sur le Crétacé inférieur marin du Sud tunisien, J. Afr. Earth Sci.

474 5. pp, 217-231. 
475 Bodin. S., Petitpierre. L., Wood. J., Elkanouni. I., and Redfern. J., 2010. Timing of early to 476 mid-cretaceous tectonic phases along North Africa: New insights from the Jeffara escarpment 477 (Libya-Tunisia). J. Afr. Earth Sci. 46, pp, 346-370.

478 Brunet. M., and Cloetingh. S., 2003. Integrated Peri-tethyan Basins studies (PeriTethys 479 Programme). Sedimentary Geology 156. pp 1-10.

480 Bumby, A. J., and Guiraud, R., 2005. The geodynamic setting of the Phanerozoic basins of 481 Africa J. Afr. Earth Sci. 43. pp, 1-12.

482 Burollet. P. F., 1991. Structures and tectonics of Tunisia. Tectonophysics 195.P, 359-369.

483 Catalano, R., Di stefano, P., Sulli, A., and Vitale, F.P., 1996. Paleogeography and structure of 484 the central Mediterranean: sicily and its offshore area. Tectonophysics 260. pp, 291-323.

485 Chaabani, F., and Razgallah, S., 2006. Aptian sedimentation: an example of interaction 486 between tectonics and eustatics in Central Tunisia. Geological Society, London, Special 487 Publications, 262. pp, 55-74.

488 Courel, L., Aït Salem, H., Benaouiss, N., Et-Touhami, M., Fekirine, B. Oujidi, M., Soussi, 489 M., and Tourani, A., 2003. Mid-Triassic to Early Liassic clastic/evaporitic deposits over the 490 Maghreb Platform. Palaeogeogr. Palaeoclimatol. Palaeoecol. 196, 157-176.

491 DeCelles, P. G., and K. N. Giles (1996), Foreland basin systems, Basin Res., 8, 105-123, 492 doi:10.1046/j.1365-2117.1996.01491.x.

493 Dercourt, J., Zonenshain, L.P., Ricou, L.P., Kazmin, V.G., Le Pichon, X., Knipper, A.L., 494 Laurier, J.P., Bashenov, M.L., Boulin, J., Pechersky, D.H., Biju Duval, B., Savostin, L.A., 495 Lepvrier, C., and Geyssant, J., 1986. Geological evolution of the Tethys belt from the atlantic 496 to the pamirs since the LIAS. Tectonophysics 123 (1-4), 241-315. 15

497 Deteil. J., Zouari. H., Chikhaoui. M., Creuzot. G., Ouali. J, Turki M. M., Yaïch. C et 498 Zargouni. F. 1991. Relation entre ouvertures téthysienne et mésogéenne en Tunisie. Bull. 499 Soc.Géol. France, t. 162, nº6 .p1173-1181. 
500 Dewey, J.F., Hempton, M. R., Kidd, W. S. F., Saroglu, F., and Segnör, A. M. C., 1986.

501 Shortening of continental lithosphere: The neotectonics of eastern Anatolia.Special

502 Publications Geological Society London 19, pp 3-36.

503 Dhahri, F., and Boukadi, N., 2010. The evolution of pre- existing structures during the

504 tectonic inversion process of the Atlas chain of Tunisia. J. Afr. Earth Sci. 56. pp 139-149.

505 Doglioni, C., Fernandez, M., Gueguen E and Sabat, F., 1999. On the interference between the 506 early Apennines-Maghrebides back arc extension and the Alps-betics orogen in the Neogene 507 geodynamics of the Western Mediterranean. Bol. Soc. Geol. Ital.118, pp 75-89.

508 Ellouz, N., Patriat, M., Gaulier, J.M., Bouatmani, R., and Sabounji, S., 2003. From rifting to

509 Alpine inversion: Mesozoic and Cenozoic subsidence history of some Moroccan basins.

510 Sedimentary Geology. 156, pp 185-212.

511 Frizon de Lamotte, D., Leturmy, P.,Missenard, Y., Khomsi, S., Ruiz, G., Saddiqi, O.,

512 Guillocheau, F., and Michard, A., 2009. Mesozoic and Cenozoic vertical movements in the

513 Atlas system (Algeria,Morocco, Tunisia): an overview. Tectonophysics. 475. pp, 9-28.

514 Frizon de Lamotte, D., Michard, A., and Saddiqi, O., 2006. Some recent developments on the

515 geodynamics of the Maghreb. C. R. Geosciences, v. 338, 1-10 n¹-2.

516 Gharbi, M., 2008. Etude Tectonique de la région de Zemlet El Beidha (Chaîne Nord des

517 Chotts) : Structuration Crétacée et Evolution Tertiaire. Mastère Fac Sci. of TunisUniversity

518 Tunis-El-Manar. 86p.

519 Guiraud, R., 1998. Mesozoic rifting and basin inversion along the northern African Tethyan

520 margin: an overview. In: MacGregor, D.S., Moody, R.T.J., Clark-Lowes, D.D. (Eds.),

521 Petroleum Geology of North Africa. Geological Society, London, Special Publication 133, pp. $522 \quad 217-229$. 
523 Guiraud, R., and Bosworth, W., 1997. Senonian basin inversion and rejuvenation of rifting in

524 Africa and Arabia: synthesis and implications to plate-scale tectonics. Tectonophysics 282, pp $525 \quad 39-82$.

526 Guiraud, R., and Bosworth, W., 1999. Phanerozoic geodynamic evolution of northeastern

527 Africa and the northwestern Arabian platform. Tectonophysics. 315, pp 73-108.

528 Guiraud, R., et Maurin, J.C., 1991. Le rifting en Afrique au Crétacé inférieur: synthèse

529 structurale, mise en évidence de deux étapes dans la genèse des bassins, relations avec les

530 ouvertures océaniques périafricaines. Bull. Soc. Géol. France 162, pp 811-823.

531 Guiraud, R., and Maurin, J.C., 1992. Early Cretaceous Rifts of Western and Central Africa.

532 An overview. Tectonophysics 213, pp 153-168.

533 Guiraud. R., and Bosworth, W., Thierry, J and Delplanque, A., 2005. Phanerozoic geological

534 evolution of Northern and Central Africa: An overview J. Afr. Earth Sci. 43, pp 83-143.

535 Herkat, M., and Guiraud, R., 2006. The relationships between tectonics and sedimentation in 536 the Late Cretaceous series of the Eastern Atlasic Domain (Algeria). J. Afr. Earth Sci. 46, pp $537 \quad 346-370$.

538 Hlaiem, A. 1999. Halokinisis and structural evolution of the major features in eastern and 539 southern Tunisian Atlas. Tectonophysics 306, pp. 79-95.

540 Laridhi-Ouazaa, N., and Bédir, M., 2004. Les migrations tectono-magmatiques du Trias au

541 Miocène sur la marge orientale de la Tunisie. Africa Geosciences Review, Vol. II, n³,

542 pp179-196.

543 Laville, E., Pique, A., Amrhar, M., and Charroud, M., 2004. A restatement of the Mesozoic

544 Atlasic Rifting (Morocco). J. Afr. Earth Sci. 38, pp 145-153.

545 Lazzez, M., and Ben Youssef, M., 2008. Relative Sea-level Changes of the Lower Cretaceous

546 Deposits in the Chotts Area of Southern Tunisia. Turkish J. Earth Sci., 17,pp 835-845. 
547 Lazzez, M., Zouaghi, T., and Ben Youssef, M., 2008. Austrian phase on the northern African

548 margin inferred from sequence stratigraphy and sedimentary records in southern Tunisia

549 (Chotts and Djeffara areas). C. R. Geosciences, v. 340. Issue 8, pp 543-555 C.

550 Louhaïchi, M. A., et Tlig, S., 1993. Tectonique synsédimentaire des séries post-Barrémiennes 551 au Nord-Est de la chaîne Nord des Chotts (Tunisie méridionale). Géologie méditerranéenne.

$552 \quad \mathrm{XX}, \mathrm{n}^{\circ} 1$, pp 53-74.

553 Marmi, R., and Guiraud, R., 2006. End Cretaceous to recent polyphased compressive

554 tectonics along the "Mole Constantinois" and foreland (NE Algeria). J. Afr. Earth Sci. 45, pp

$555123-136$.

556 Martinez, C., Chikhaoui, M., Truillet, R., Ouali, J., and Creuzot, G., 1991. Le contexte

557 géodynamique de la distension albo-aptienne en Tunisie septentrionale et centrale:

558 structuration éocrétacée de l’Atlas tunisien. Eclogae Geologicae Helvetiae 84, pp 61-82.

559 Masrouhi, A. and Koyi. H., 2012. Submarine “salt glacier” kinematics of Northern Tunisia, a

560 case of Triassic salt mobility in North African Cretaceous passive margin. Alsop, G. I.,

561 Archer, S. G., Hartley, A., Grant, N. T and Hodgkinson, R. J. Geol. R. (eds) 2012. Salt

562 Tectonics, Sediments and Prospectivity. Geological Society, London, Special Publications,

563 363, pp 579-593. http://dx.doi.org/10.1144/SP363.29.

564 Masrouhi, A., Ghanmi, M., Ben Slama, M.-M., Ben Youssef, M., Vila, J.-M, and Zargouni,

565 F., 2008. New tectono-sedimentary evidence constraining the timing of the positive tectonic

566 inversion and the Eocene Atlasic phase in northern Tunisia: Implication for the North African

567 paleo-margin evolution. C. R. Geosciences, 340. pp 771-778.

568 Masrouhi, A., Ghanmi, M., Youssef, M.B., Vila, J.M., and Zargouni, F., 2007, Mise en

569 évidence d’une nappe de charriage à deux unités paléogènes au plateau de Lansarine (Tunisie

570 du Nord): Définition d’un nouvel élément structural de l’Atlas Tunisien et réévaluation du

571 calendrier des serrages tertiaires: C. R. Geosciences, v. 339, p. 441-448. 
572 Patriat, M., Ellouz N., Dey Z., Gaulier J. M., and Ben Kilani H., 2003. The Hammamet,

573 Gabes and Chotts basins (Tunisia) a review of the subsidence history. Sedimentary geology 574 156, pp 241-262.

575 Negra, M. H., Purser, B. H., M'rabet, A. 1995. Sedimentation, diagenesis and syntectonic 576 erosion of Upper Cretaceous rudist mounds in central Tunisia. Carbonate mud-mounds: their 577 origin and evolution, pp. 401-419.

578 Philip, H., Andrieux, J., Dlala, M., Chihi, L., and Ben Ayed, N., 1986. Evolution tectonique 579 moi- plio-quaternaire du fossée de Kasserine (Tunisie centrale): implications sur l'évolution 580 géodynamique récente de la Tunisie. Bull. Soc. Géol. France, 8 t. II, 4, 559-568.

581 Piqué, A., A Brahim., L., Ait Ouali, R., Amrhar, M., Charroud, M., Gourmelen, C., Laville,

582 E., Rekhiss, F., and Tricart, P., 1998. Evolution structurale des domaines atlasiques du 583 Maghreb au Méso-Cénozoïque; le rôle des structures héritées dans la déformation du domaine 584 atlasique de l’Afrique du Nord. Bull. Soc. Géol. France, 6 t. 169, 797-810. pp.217-231.

585 Piqué, A., Tricart, P., Guiraud, R., Laville, E., Bouaziz, S., Amrhar, M., and Ait Ouali, R., 586 2002. The Mesozoic-Cenozoic Atlas belt (North Africa): an overview. Geodinamica Acta 15, $587 \quad$ pp185-208.

588 Raulin, C., Lamotte, D.F.D., Bouaziz, S., Khomsi, S., Mouchot, N., Ruiz, G., Guillocheau, F. 589 2011. Late Triassic-early Jurassic block tilting along E-W faults, in southern Tunisia: New 590 interpretation of the Tebaga of Medenine. Journal of African Earth Sciences 61, pp. 94-104

591 Rigane, A., Feki, M., Gourmelen, C., and Montacer, M., 2010. The “Aptian Crisis” of the 592 South-Tethyan margin: New tectonic data in Tunisia. J. Afr. Earth Sci. 57. pp. 360-366. 593 Souquet, P., Peybernès, B., Saadi, J., BenYoussef, M., Ghanmi, M., Zarbout, M., Chikhaoui, 594 M., and Kamoun, F., 1997. Séquences et cycles d’ordre 2 en régime extensif et transtensif: 595 exemple du Crétacé inférieur de l’Atlas tunisien, Bull. Soc. geol. France 168, pp. 373-386. 
596 Soyer, C. and Tricart, P., 1987. La crise aptienne en Tunisie centrale : approche

597 paléostructurale aux confins de l'Atlas et l'Axe Nord-Sud. C.R. Acad. Sci. Paris. t. 305 (Serie

$598 \quad$ II), pp. 301-305.

599 Vergès, J. and Sabàt, F., 1999. Constraints on the western Mediterranean kinematics evolution

600 along a $1000 \mathrm{~km}$ transect from Iberia to Africa. In: Durand, B. (Ed.). The Mediterranean

601 Basins: Tertiary Extension within the Alpine Orogen, vol. 156. Geol. Soc. Spec. Publ.,

602 London, pp. 63-80.

603 Vially, R.; Letouzey, J.; Bernard, F.; Haddadi, N.; Desforges, G.; Askri, H.and Boudjema, A., 6041994 . Basin inversion along the northern African margin: the Saharan Atlas (Algeria). In:

605 Peri-Tethyan Platforms, F. Roure (Ed.), pp. 79-118, Edition Technip, Paris.

606 Zargouni, F., 1984. Style et chronologie des déformations des structures de l’Atlas tunisien

607 méridional. Évolution récente de l’accident Sud-atlasique. C.R. Acad Sc.Paris, t.299, Série II, $608 \quad n^{\circ} 2 . p p \cdot 179-196$.

609 Zargouni, F., 1985. Tectonique de l'Atlas méridional de Tunisie, évolution géométrique et 610 cinématique des structures en zone de cisaillement. Thèse d'Etat, Univ. Louis Pasteur,

611 Strasbourg-Paris.

612 Zargouni, F., Rabiaa, M.C., et Abbés, C., 1985. Rôle des couloirs de cisaillement de Gafsa et

613 de Négrine-Tozeur dans la structuration du faisceau des plis des Chotts, éléments de l'accident

614 sud-atlasique. C.R. Acad Sc.Paris, t 301. 11, pp. 831-883.

615 Zghal. I, Ouali. J, et Bismuth, H. 1998. Syn-sedimentary tectonics in central Tunisia (Jebel

616 Mrhila area) during the Aptian-Albian. C.R. Acad Sc Paris, V 326, 3, pp 187-192.

617 Zouaghi, T., Bédir, M., and Inoubli, M, H., 2005. 2 D Seismic interpretation of strike-slip

618 faulting, salt tectonics, and Cretaceous unconformities, Atlas Mountains, central Tunisia. J.

619 Afr. Earth Sci. pp. Vol. 43, pp 464-486. 
620

621

622

623

624

625

626

627

628

629

630

631

632

633

634

635

636

637

638

639

640

641

642

643

Zouaghi, T.; Ferhi, I.; Bédir, M.; Ben Youssef, M.; Gasmi, M. and Inoubli, M.H., 2011.

Analysis of Cretaceous (Aptian) strata in central Tunisia, using 2D seismic data and well logs. . Afr. Earth Sci. Vol. 61, pp. 38-61.

Zouari, H., Turki, M.M., Delteil, J., et Stephan, J.-F., 1999. Tectonique transtensive de la paléomarge tunisienne au cours de l’Aptien-Campanien. Bull. Soc. Géol. France 170 (3), pp. 295-301.

\section{Figure captions}

Figure 1: Structural map of the northern African margin. B. Tectonic background of the southern Atlas of Tunisia is mapped based on satellite images analysis and field investigations (The base map is produced using elevation data from NASA SRTM Gtopo 30). C. Geological map of the North Chotts range with the location of Zemlet el Beidha.

Figure 2: Detailed geologic map of the Zemlet el Beidha anticline. Location of Fig. 5 is shown. The cross sections A-A' and B-B' are located in Fig. 4.

Figure 3: Stratigraphic column of the Mesozoic and Cenozoic series in the Zemlet el Beidha region. Only the outcropping series are shown.

Figure 4: Surface cross sections (For location, see Fig. 2) across the Zemlet El Beidha anticline. Section $\mathrm{A}-\mathrm{A}^{\prime}$ demonstrates the reactivation of the normal fault as reverse fault in the east of Tebaga Fatnassa structure. Section (B-B') shows the role of the NW-SE strike slip fault of the Fejej system (Fig. 2) affecting the southwestern part of Zemlet el Beidha.

Figure 5: A: The SPOT image of the Khanguet Aïcha area; B: Interpretative geological and structural map of Khanguet Aïcha area; C: The correlation of Barremian deposits with the normal fault of Khanguet Aïcha; D: Lower hemisphere stereographic projection of planes and striations of the Khanguet Aïcha and Khanguet Amor faults. The back-tilting shows the existent N100-110 E trending normal fault of Khanguet Aïcha and Khanguet Amor. 
644 Figure 6: A: Panoramic view of the tilted synsedimentary Khanguet Aicha normal fault. This

645 fault affects the Sidi Aïch and Orbata Formations and is sealed by the Coniacian-Santonian

646 strata. B: Photograph of the tilted Khanguet Amor normal fault associated with syntectonic

647 conglomerates of the Orbata Formation.

648 Figure 7: Details of the Aptian syn-tectonic conglomerates of the Orbata Formation.

649 A: The Aptian conglomerate; B: The metric bed of Aptian conglomerates located in the

650 Khanguet Amor (See fig. 2); C and D: Small conglomerates resedimented in the Khanguet

651 Aicha and Khanguet Amor.

652 Figure 8: Panoramic view, looking ENE, of a preserved Early Cretaceous normal fault. For

653 location, see Fig. 2 Growth strata located in the hanging-wall indicate that this normal fault

654 was active at least during the Albian.

655 Figure 9: Shortcut inverted normal fault with hangingwall shortcut deformation in the

656 Bouhedma Formation.

657 Figure 10: A: NE-SW correlations of Cretaceous sedimentary log in the Zemlet el Beidha

658 This correlation shows evidence of a central horst (Zemlet el Beidha) and lateral grabens

659 (Fejej and Romana). Note the major thickening of the Cretaceous sediments toward the major

660 faults. B: Block diagram showing tilted half graben systems of the Zemlet el Beidha as a

661 result of a N to NE extension during Aptian-Albian(see Fig.5 D).

662 Figure 11: Photographs showing the principal features of the extensional Cretaceous along

663 the Zemlet el Beidha structure. (A) The olistholites within the Bouhedma Formation indicate

664 the depositional syn-rift. (B) Conglomerate interstratified in the Bouhedma Formation. (C)

665 Ammonite Aptian in the Orabata Formation. (D) Rudist fossils (arrows) within the Aleg

666 Formation (Coniacian-Santonian).

667 Figure 12: Seismic reflexion profiles EL05 and EL07 across the Sidi Mansour Basin,

668 showing horst and graben systems trending NNE-SSW related to the extension of the 
669 Tethyan margin. The base map is produced using elevation data from NASA SRTM Gtopo

670 30shows the position of seismic sections and the locations of petroleum wells used in this

671 study.

672 Figure 13: Interpretative model of Khanguet Aicha fault: genetic mechanism explaining the 673 presence of sedimentary discontinuity ds1 and ds2 of the upper Aptian and Early Albian

674 deposit related to extensional tectonic. See details in the text.

675 Figure 14: Similar Aptian-Albian extensional structures observed in the southern Atlas of

676 Tunisia. A: The core of the Chemsi anticline shows, still preserved, a normal fault affecting

677 the Albian series; B: Graben in the Aptian series; C: Map view (Google Earth image) of the

678 Jebel Tebaga of Kebili. The geological interpretation shows that the Orbata Formation is

679 affected by the normal fault, sealed by the Zebbag Formation.

680 Table 1: Biostratigraphic data from the Zemlet el Beidha. Location of sample are in meter

681 (UTM system). Microfauna and corresponding age of samples are also shown. 

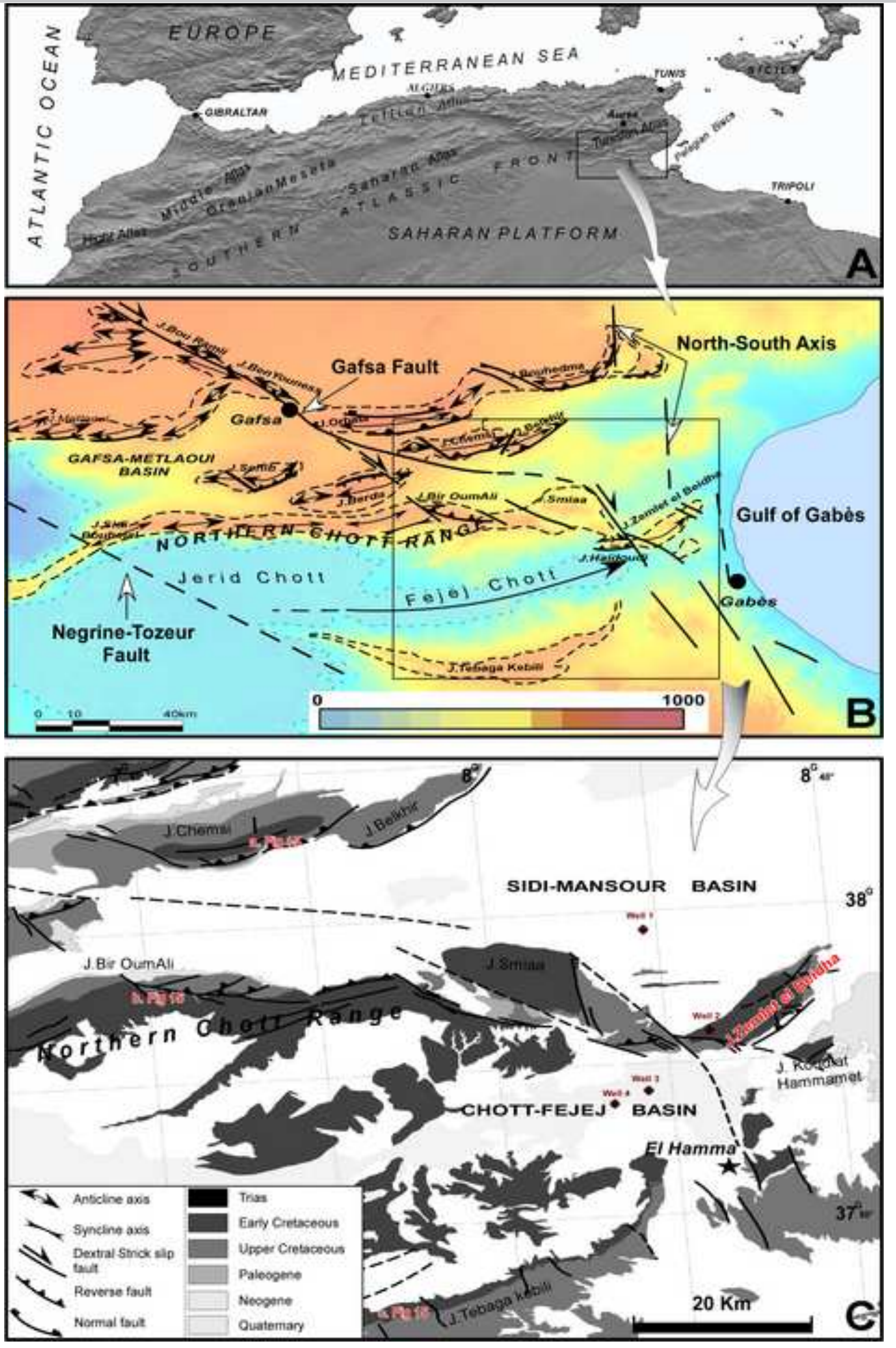
ACCEPTED MANUSCRIPT
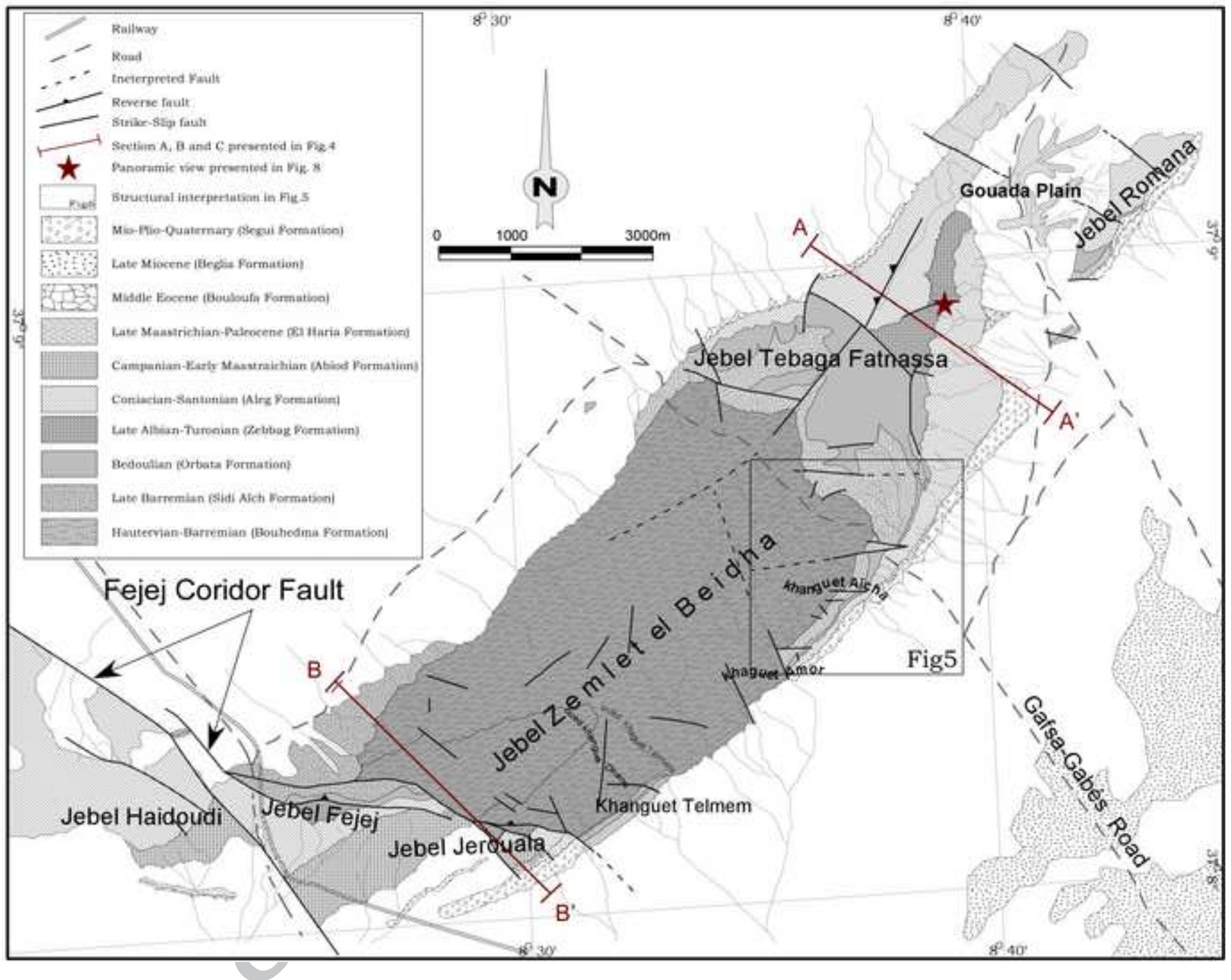
ACCEPTED MANUSCRIPT

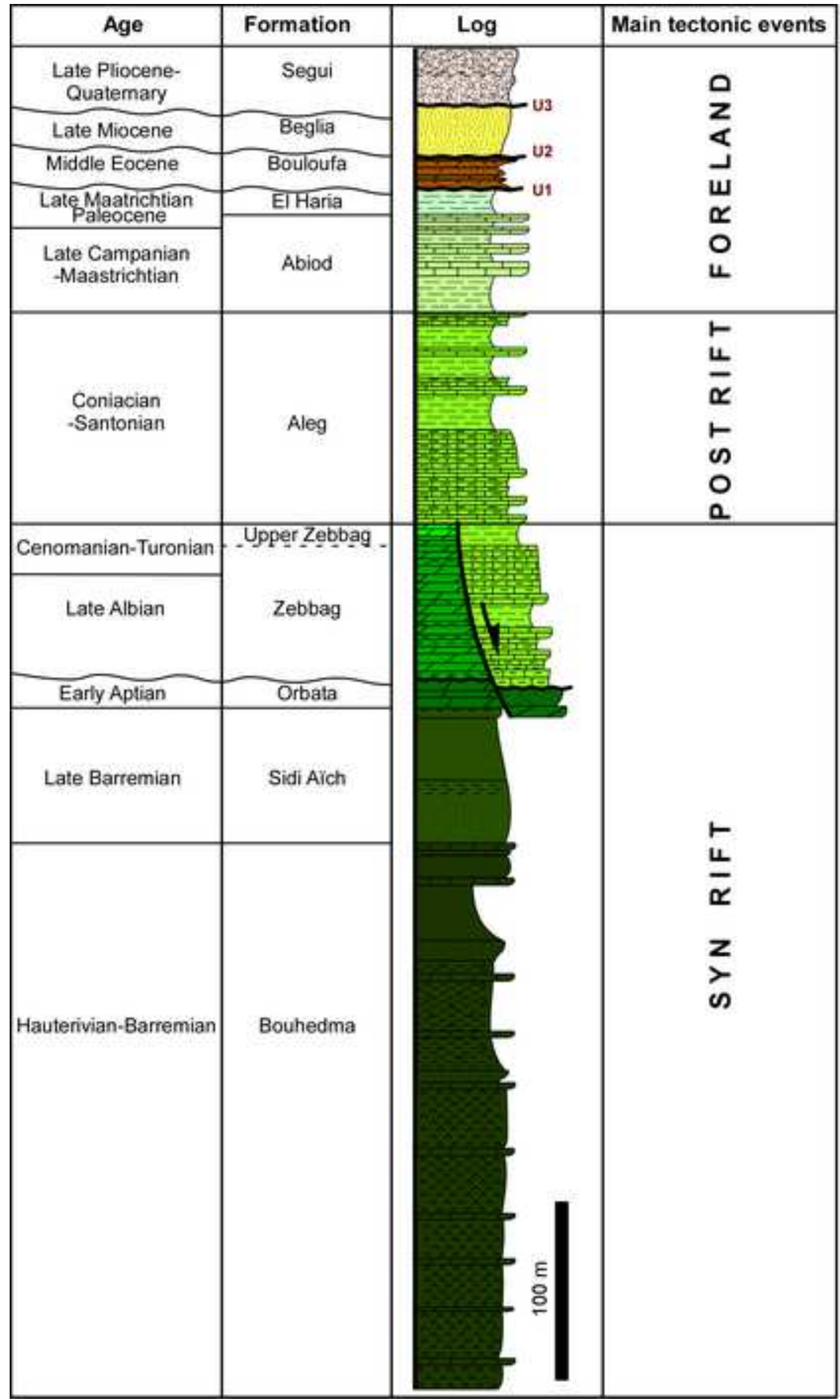

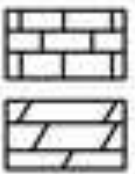

Limestone

Dolomite

1 舀-1 $=-2$ Clay Marle

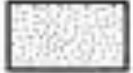

Sand

Conglomerate $\hat{A \wedge} \wedge \hat{n}$ Gypsum 


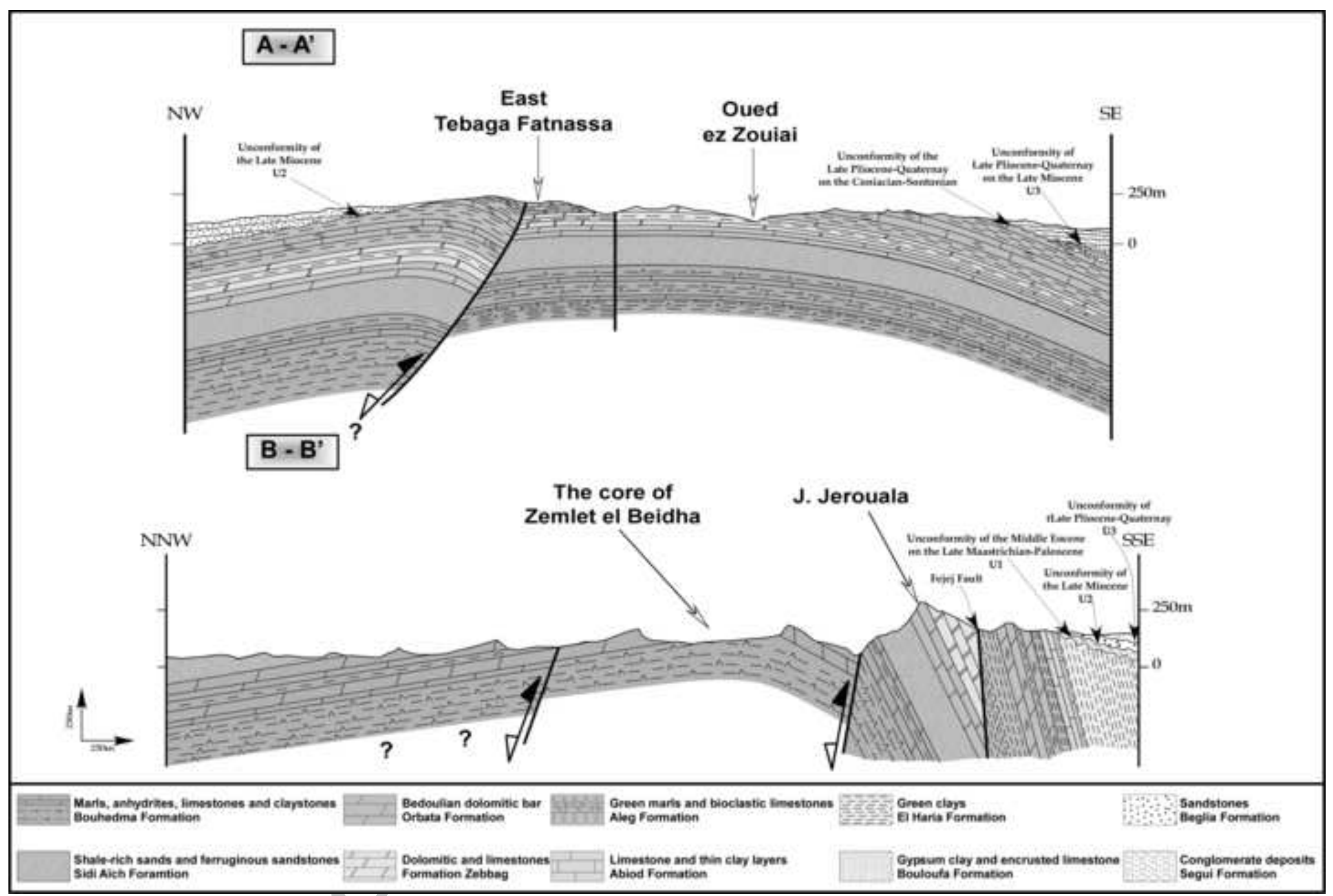


ACCEPTED MANUSCRIPT

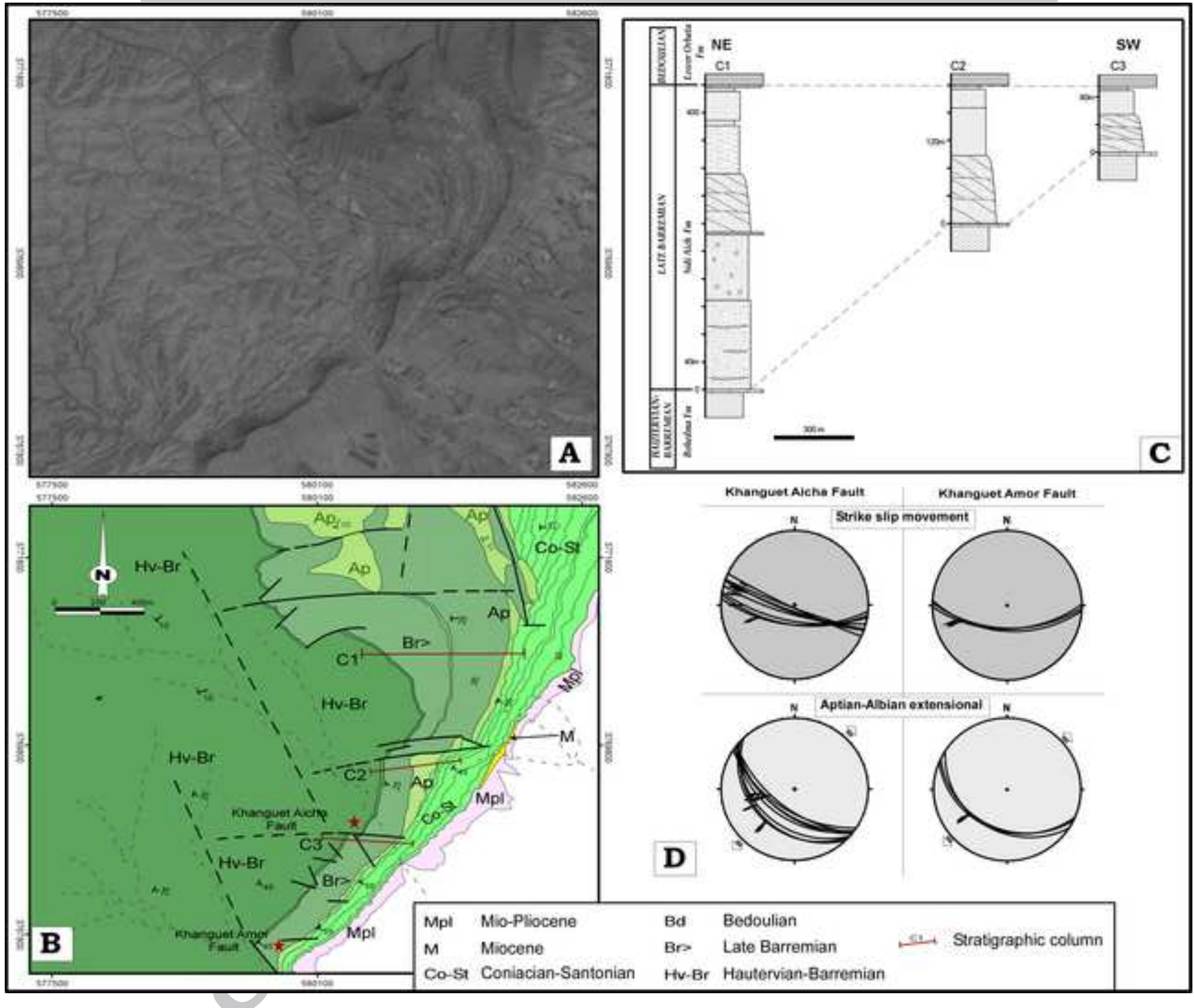



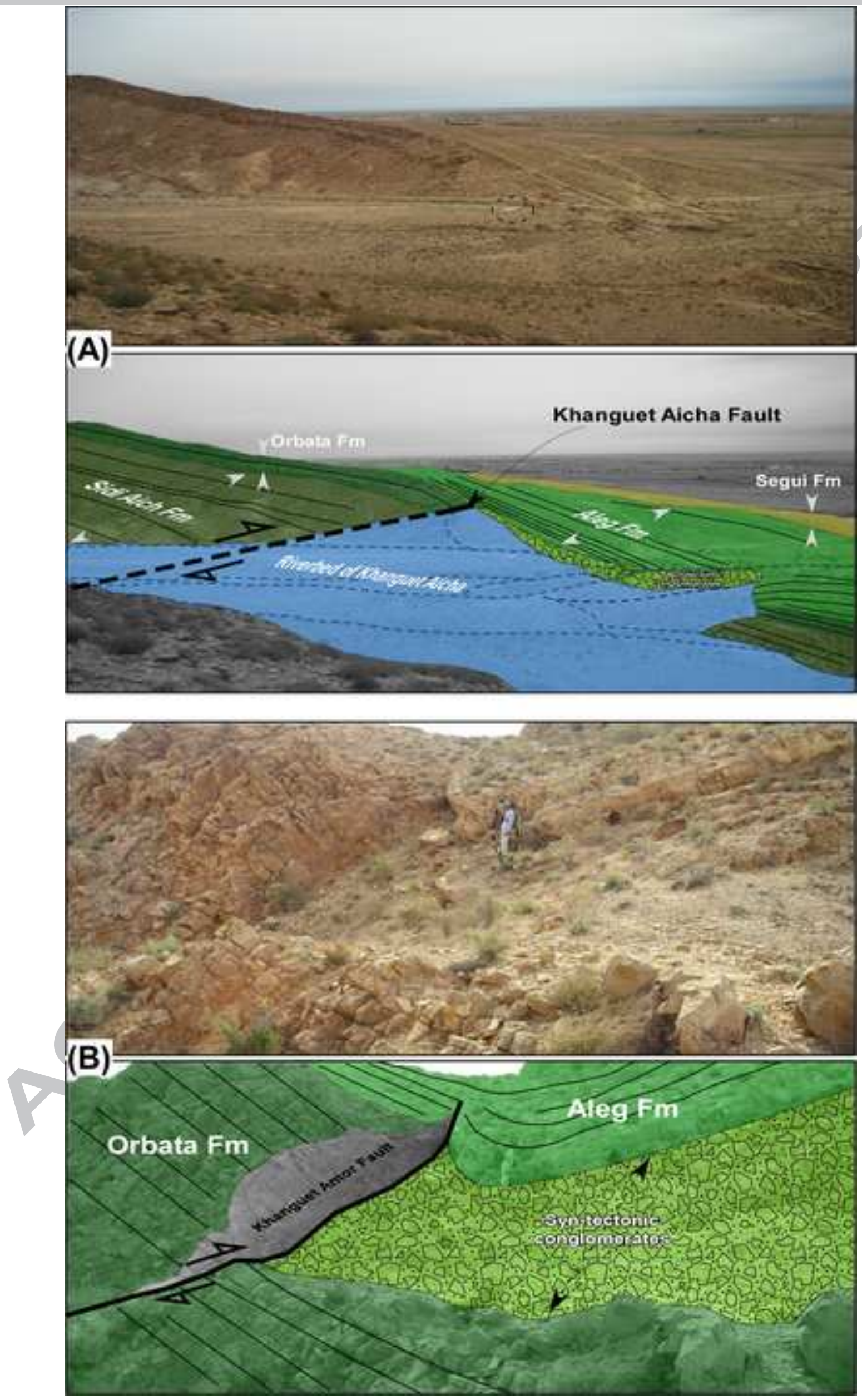

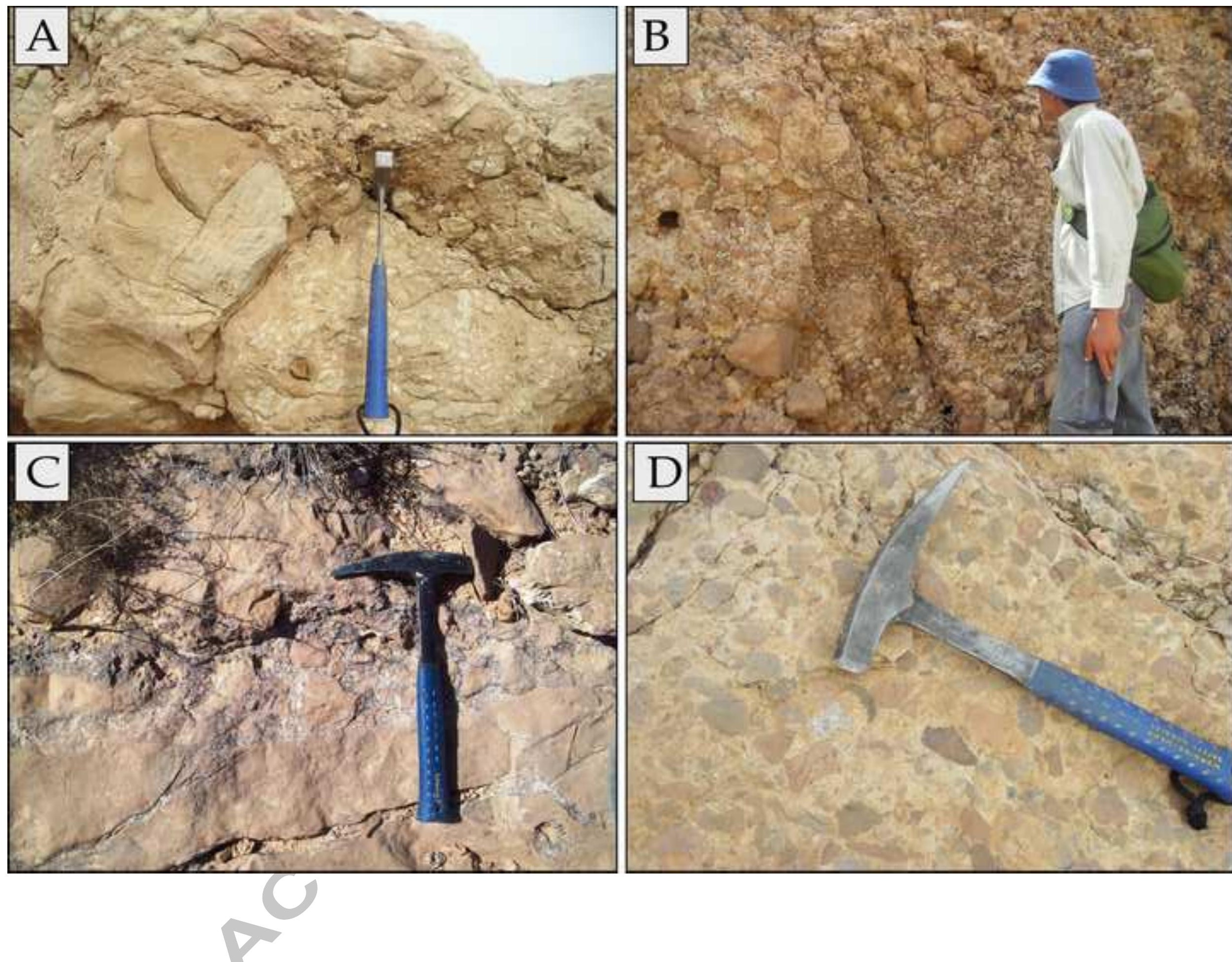
$\nabla$ 

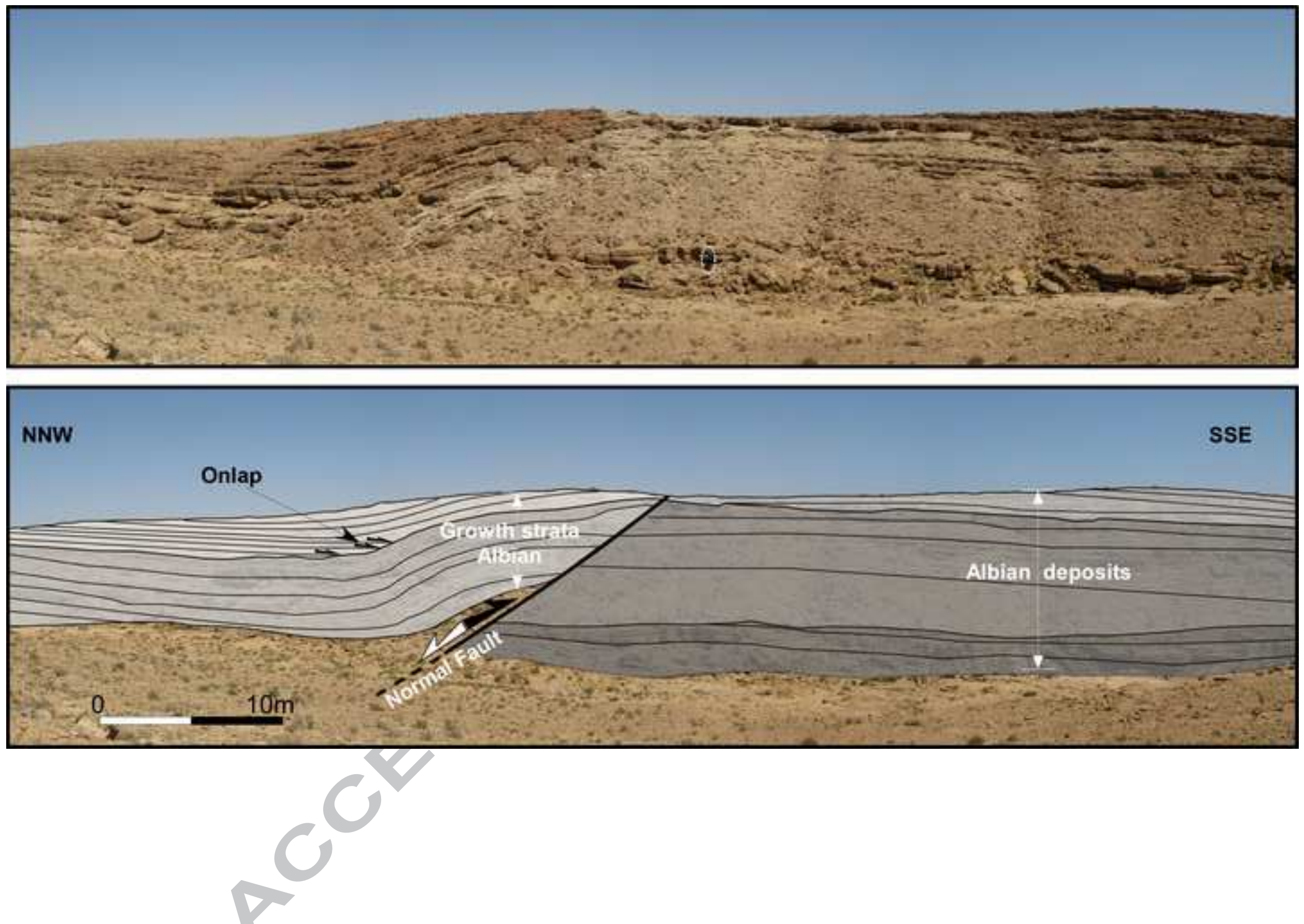


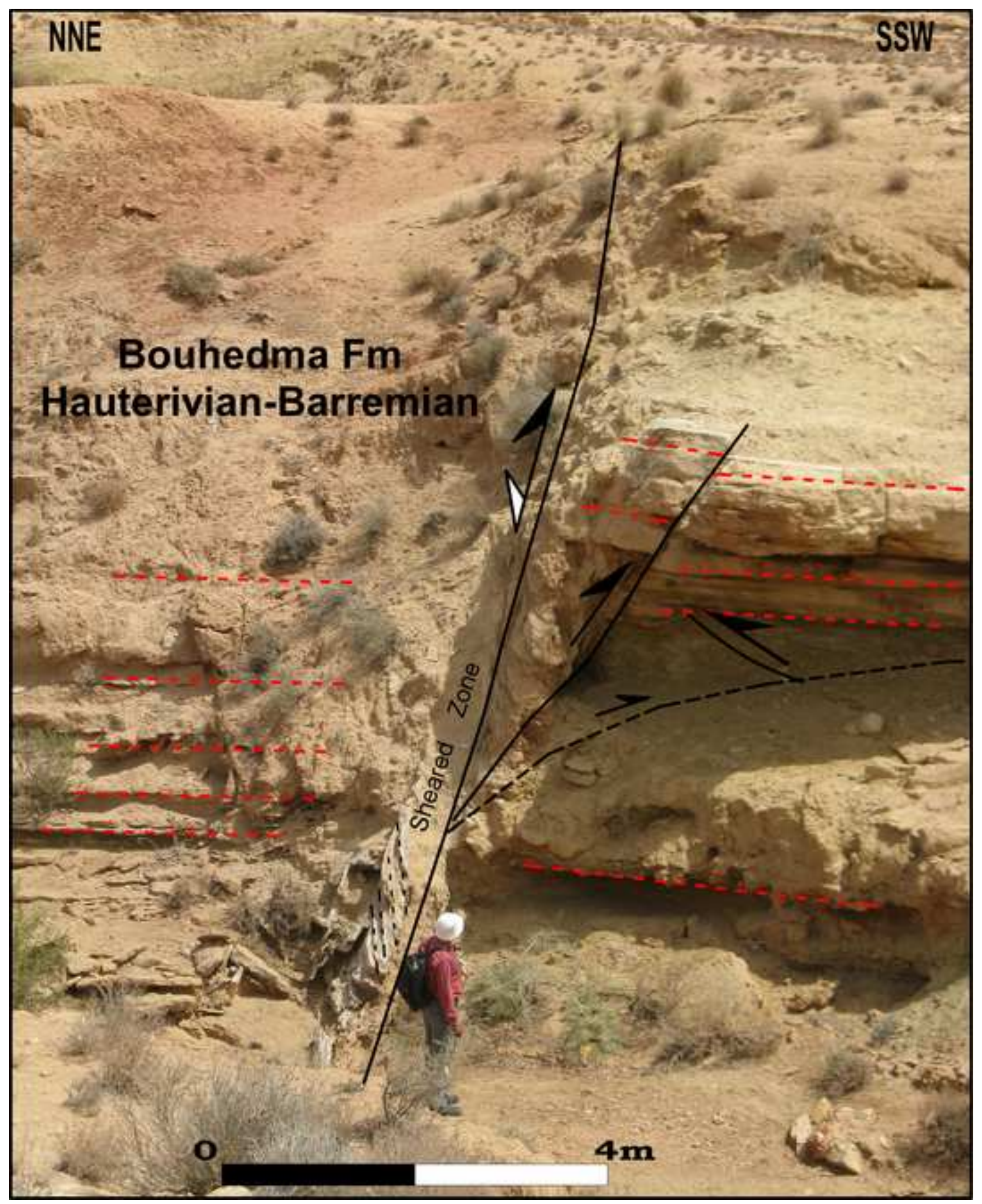


ACCEPTED MANUSCRIPT
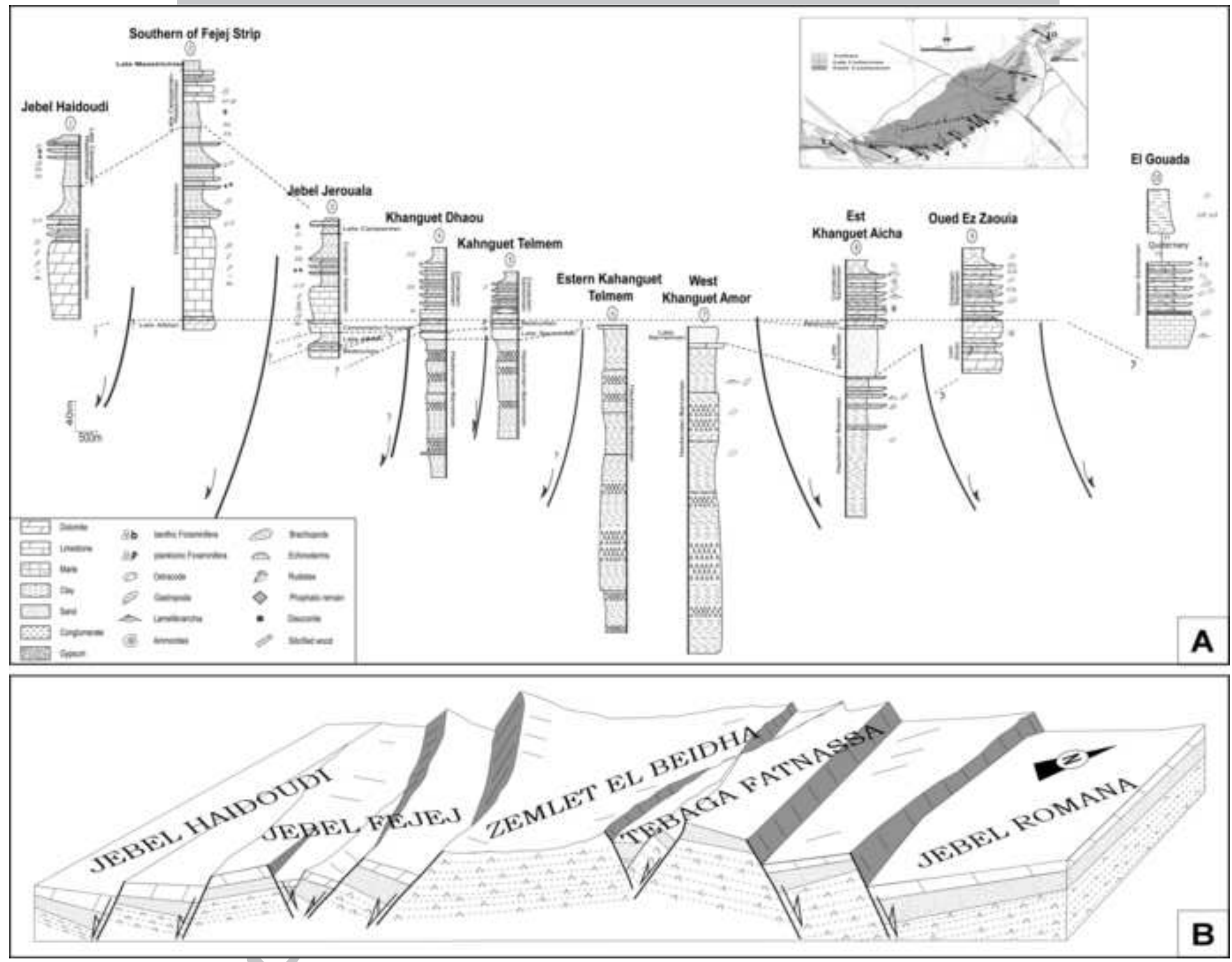

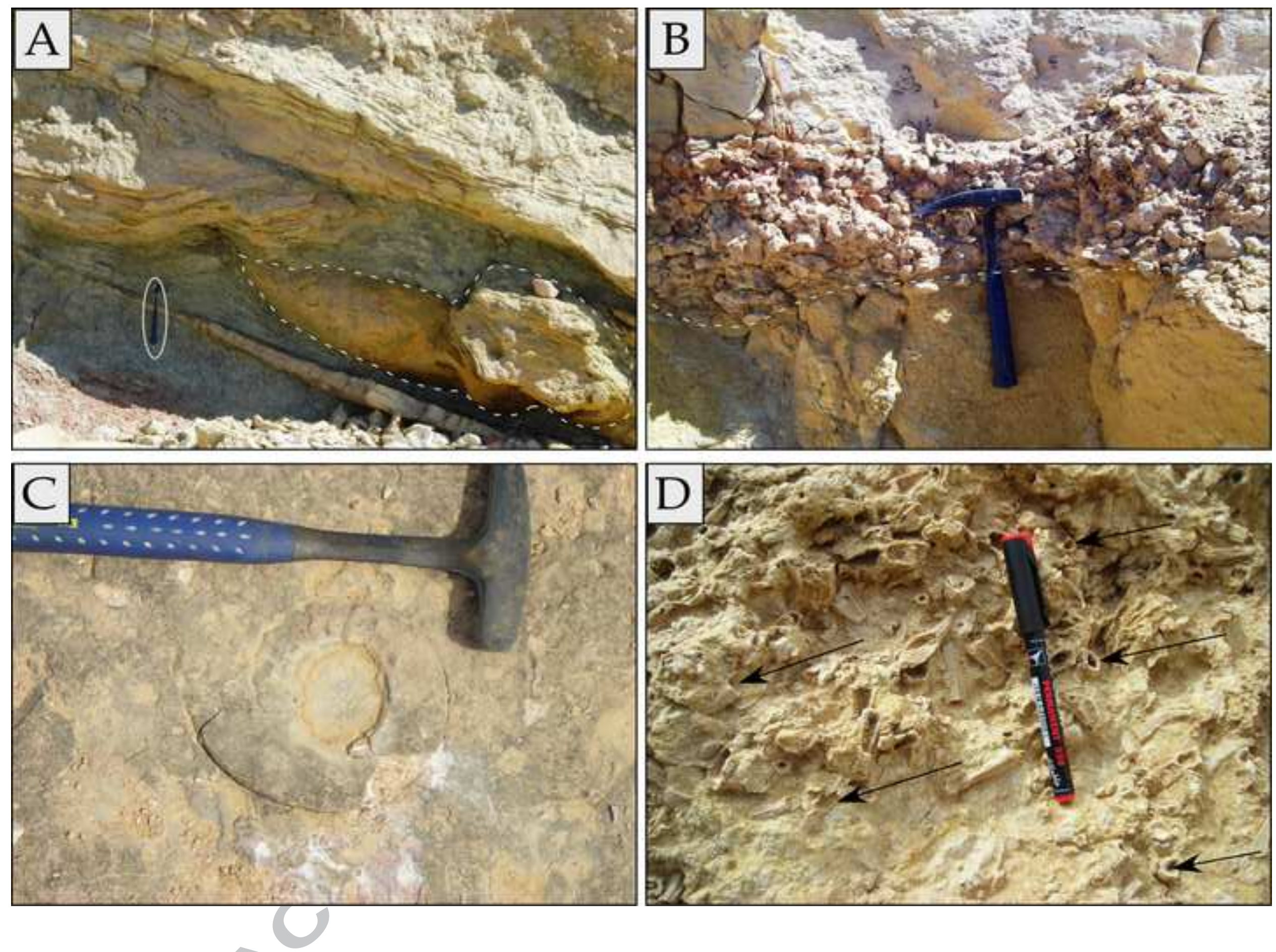

$\nabla$ 
ACCEPTED MANUSCRIPT

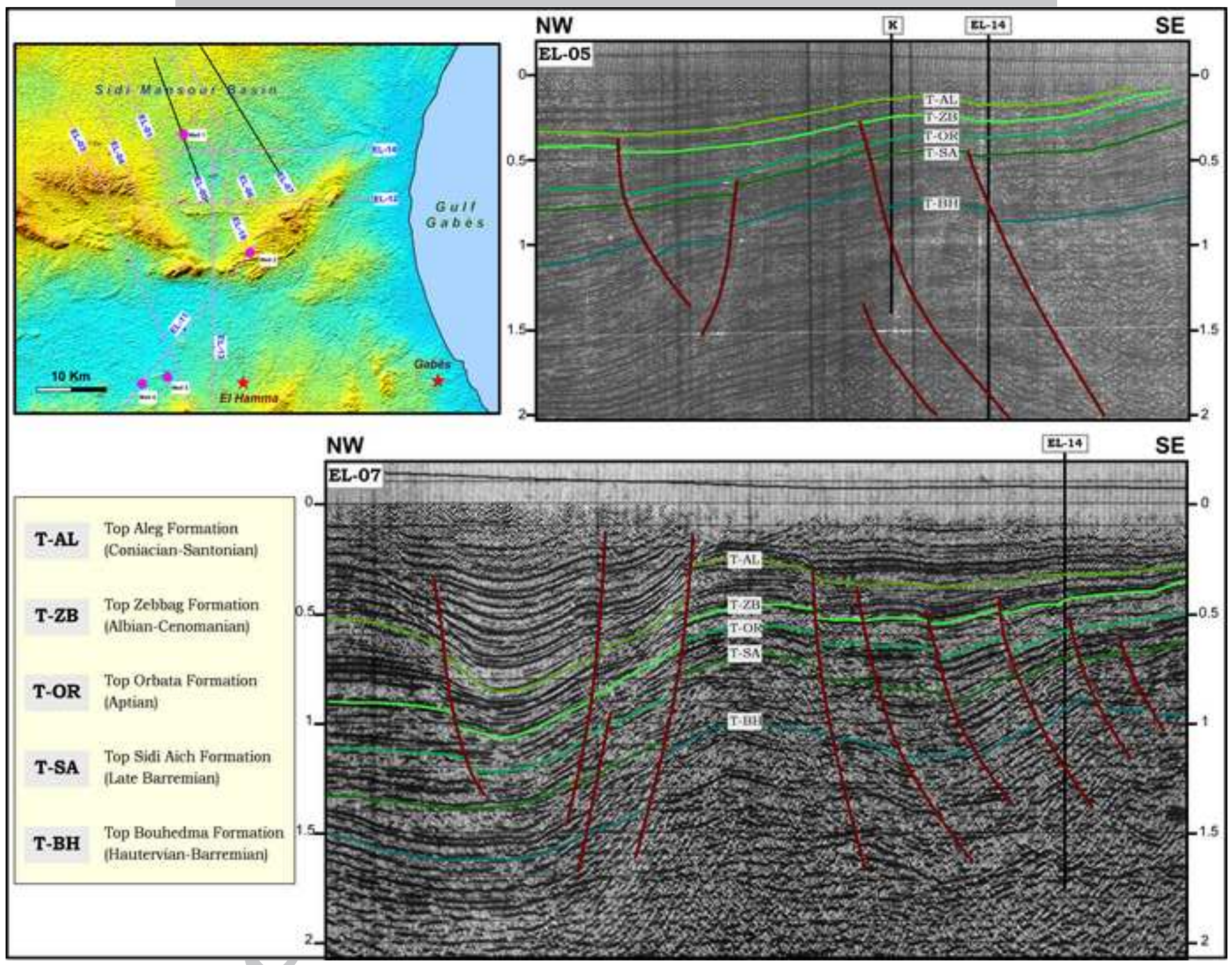




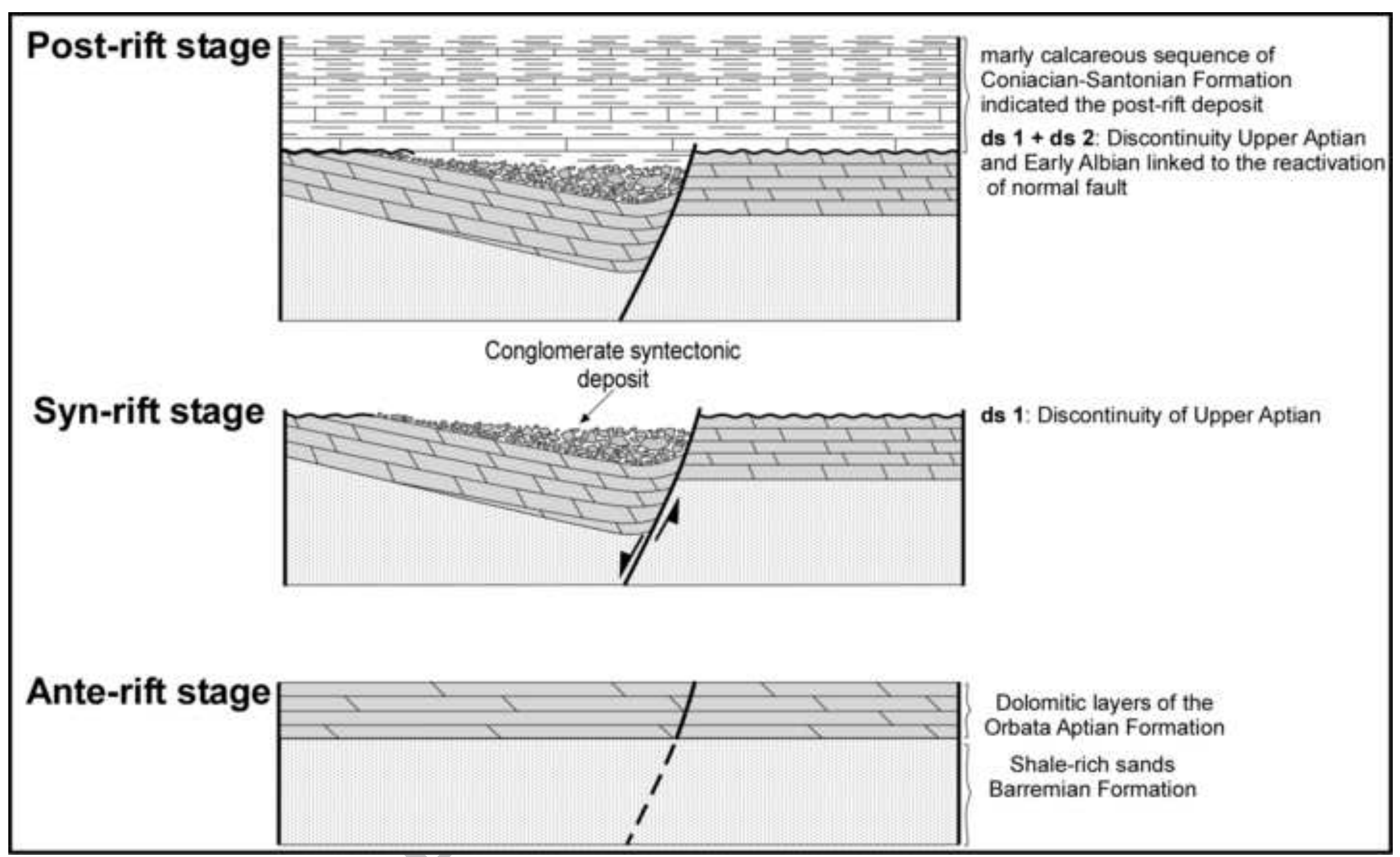



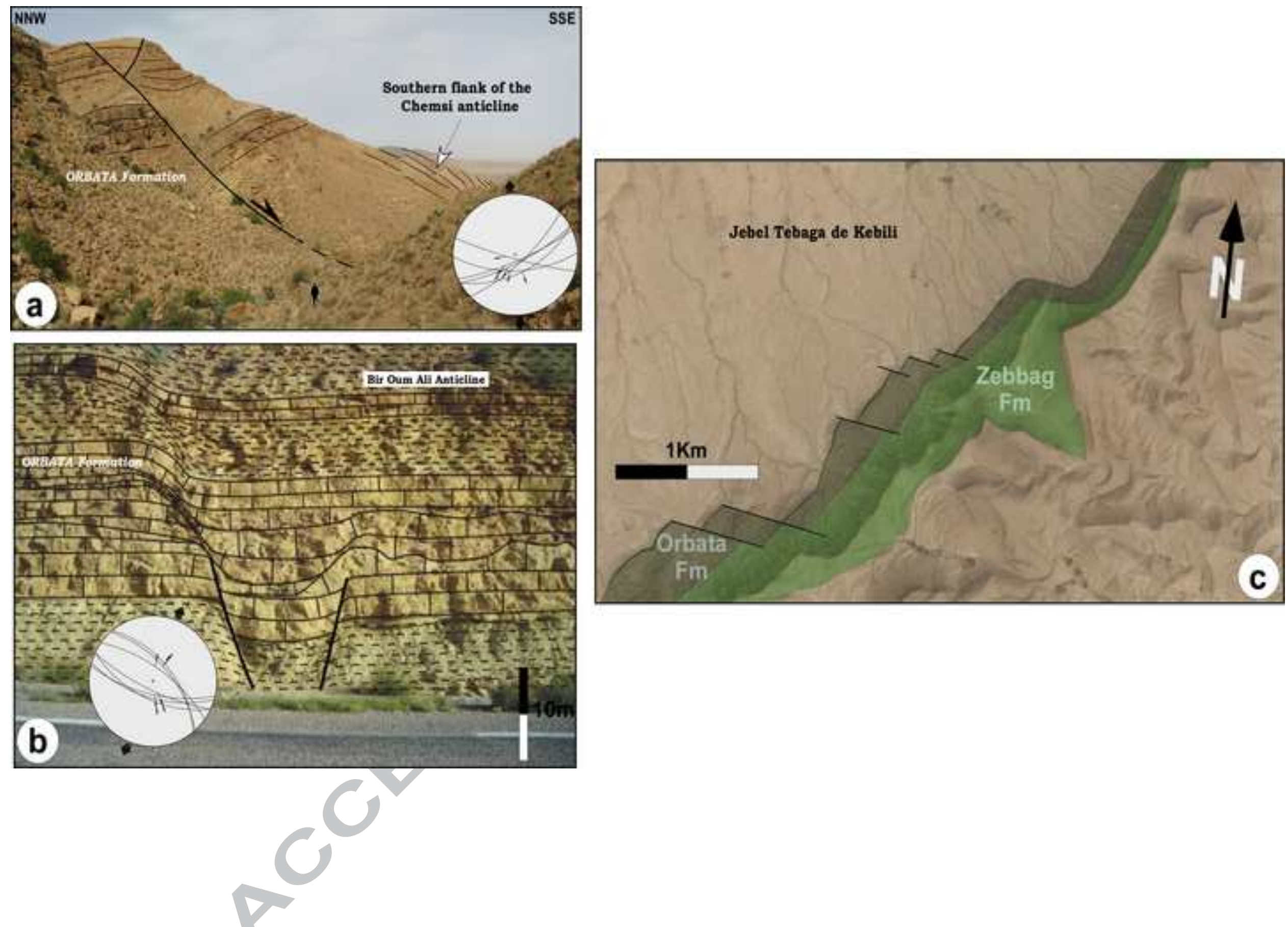


\begin{tabular}{|c|c|c|c|c|c|}
\hline Locality & $\mathrm{Nb}$ & 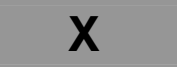 & $\mathbf{Y}$ & Fauna & Age \\
\hline \multirow{6}{*}{ Jebel Romana-Gouada plain } & EH 152 & 585047 & $3,775,657$ & Echinoderme, Cytherella sp, Cythereis sp, Brachycythere & Coniacian-Santonian \\
\hline & EH 153 & 585000 & $3,775,593$ & Radiole, Cytherella sp, Bairdia sp & Coniacian-Santonian \\
\hline & EH 155 & 584483 & $3,775,204$ & Rotallia, Gavelinella sp, Lenticulina sp. & Coniacian-Santonian \\
\hline & EH 156 & 582497 & $3,775,659$ & Rotallia, Gavelinella $s p$ & Coniacian-Santonian \\
\hline & $\mathrm{EH} 220$ & 584,262 & $3,774,591$ & Brachycythere, Globotruncana fornicata, Bairdia sp. & Coniacian-Santonian \\
\hline & $\mathrm{EH} 221$ & 584,257 & $3,774,589$ & Globotruncana fornicata, Globigerinelloides aspera, Lenticulina. & Coniacian-Santonian \\
\hline \multirow{6}{*}{$\begin{array}{c}\text { Tebaga Fatnassa-Oued ez } \\
\text { Zouaia }\end{array}$} & $\mathrm{EH} 118$ & 580,635 & $3,774,718$ & Ammonites, Cytherella sp, Bairdia sp, & Coniacian-Santonian \\
\hline & EH 124 & 581,839 & $3,773,088$ & Ammonites, Brachycythere, Bairdia sp, & Coniacian-Santonian \\
\hline & $\mathrm{EH} 125$ & 581,752 & $3,773,090$ & Ammonites, Echinodermes, Ostreas, Cytherella sp. & Coniacian-Santonian \\
\hline & EH 128 & 581,199 & $3,773,404$ & Dawinula sp, Cythereis sp & \multirow{2}{*}{ Late Albian } \\
\hline & $\mathrm{EH} 130$ & 578,345 & $3,773,830$ & Radiole, Ammonites, Brachycythere. & \\
\hline & EH 113 & 579,411 & $3,770,340$ & Cypridea, Cytherella, Choffatella decipiens & Barremian \\
\hline \multirow{2}{*}{ Khanguet Aicha-khanguet Amor } & $\mathrm{EH} 131$ & 577,676 & $3,768,980$ & Fabanella, Cypridea, Choffatella decipiens, Fabenella sp, Perissocytheridea & Barremian \\
\hline & EH 173 & 580,877 & $3,769,897$ & Cythertlia dextrocepematta, Numidica, Cytherella & Coniacian \\
\hline \multirow{6}{*}{$\begin{array}{l}\text { Jebel Jerouala } \\
\text { Khanguet Telmem-khanguet Dhaou }\end{array}$} & $\mathrm{EH} 176$ & 580,934 & $3,769,897$ & Echinoderme, Cytherella sp, Cythereis sp, Brachycythere & Coniacian-Santonian \\
\hline & EH 142 & 571,821 & $3,766,103$ & Rotalia, Protobontomia numidica, Gavelinella sp, Globotruncana lapparenti. & Coniacian-Santonian \\
\hline & $\mathrm{EH} 143$ & 571,841 & $3,766,101$ & Brachycythere, Cytherella. & Coniacian-Santonian \\
\hline & EH 145 & 572,474 & $3,765,998$ & Knemiceras, Darwinula sp, pracypris $s p$ & Late Albian \\
\hline & $\mathrm{EH} 183$ & 573,864 & $3,765,434$ & Cythereis sp, Spiroplectamira sp, Lenticulina sp, Globotruncana arca, Orbitoides. & Late Campanian \\
\hline & EH 184 & 573,956 & $3,765,399$ & Hedbergella sp, Nodosaria sp, Globotruncana fornicata, Pseudotextularia nutalli. & Late Campanian-Maastrichian \\
\hline & EH 185 & 574,019 & $3,765,358$ & Protobontonia sp, Hedbergella, Textularia. & Coniacian \\
\hline & $\mathrm{EH} 226$ & 575,959 & $3,765,811$ & Rudiste. & Turonian \\
\hline & $\mathrm{EH} 196$ & 574,228 & $3,765,587$ & Cytherelle, Radiole, Ostriea & Coniacian \\
\hline \multirow{6}{*}{ Jebel Fejej } & EH 104 & 567,146 & $3,768,270$ & Echinoderme, Ammonites & Coniacian \\
\hline & $\mathrm{EH} 107$ & 568,910 & $3,765,986$ & Vaginulopsis sp, Globotruncana arca, & \multirow{2}{*}{ Late Campanian } \\
\hline & EH 109 & 568,457 & $3,766,134$ & Globotruncana rugosa, Macrocypris sp, Globotruncana fornicata. & \\
\hline & $\mathrm{EH} 140$ & 570,900 & $3,765,808$ & Echinoderme, Cytherella sp, Cythereis sp, Brachycythere & I ate Camnanian-Maastrichian \\
\hline & $\mathrm{EH} 142$ & 570,926 & $3,765,758$ & Globotruncana fournicata, Globigerinelloides aspera, Lenticulina. & Late Campanian-iviáastricnian \\
\hline & EH 143 & 570,999 & $3,765,737$ & Rotallia, Gavelinella sp, Lenticulina sp, Brachycythere. & Coniacian-Santonian \\
\hline \multirow{4}{*}{ South Jebel Haidoudi } & $\mathrm{EH} 200$ & 568,491 & $3,765,622$ & Globotruncana, Lenticulina & \multirow{4}{*}{$\begin{array}{c}\text { Coniacian-Santonian } \\
\text { Late Campanian-Maastrichian } \\
\text { Paleocene? }\end{array}$} \\
\hline & $\mathrm{EH} 201$ & 568,431 & $3,765,659$ & Echinoderme, Cytherella sp, Cythereis sp, Brachycythere & \\
\hline & EH 202 & 568,484 & $3,765,108$ & Hedbergella sp, Globotruncana fornicata, Pseudotextularia nutalli, Vaginulopsis $s p$. & \\
\hline & EH 207 & 568,356 & $3,764,916$ & Subbotina triloculinoides, Gavelinella danica, Bairdia sp, Globotruncana fornicata. & \\
\hline
\end{tabular}


684

685

Highlights:

686 We used new data to examine inheritance Cretaceous structure pattern of Atlassic front.

687 Most faults were active during Aptian Albian times of rifting stage.

688

- Lower Cretaceous rifting structure are sealed by Coniacian Santonian post-rift deposits.

689 